


\title{
MARKETING MANAGEMENT
}

\author{
Boby Thomas \\ MCom, MPhil, MA (Eco.), MA (Phil.), BEd \\ Pavanatma College, Murickassery, Idukki
}




\section{MARKETING MANAGEMENT}

ISBN: 978-81-937939-3-0 (E Book)

ISBN: 978-81-937939-2-3 (Print)

Published by

Ambitious Books Private Limited

http://www.abplpublications.website http://www.abplpublications.co.in 


\section{PREFACE}

Marketing is an interesting area, where the customers are focused rather than any other element. Few years back I had an interesting experience with one of the leading textile show rooms in Kerala. Upon entering the floor, I was asked by the lady 'Whether I am looking for welladvertised discount floor or normal floor.' Though not aware of their advertisement of 'discount mela', out of curiosity, I have opted for the discount floor. I was just in search of a formal long trouser. There the price was bit high, but all offered 50\% discount. Without selecting any item, I just asked the salesman to direct me to the normal floor. He looked me in wonder, as did many other customers on the floor. What a fool to drop all these $50 \%$ discounts. On the same building branded products are offered at nearly half the price, but without any discount! I could never imagine that a merchant would be bold enough to do it. But they did, and was successful in their business.

Every marketing technique becomes successful, when the market is observed and studied. Discount expecting customers form a separate segment of the market, and they will hardly visit non discount floors. They are happy with the amount of discount, irrespective of the actual price. 
This text book on 'Marketing Management', does not cover the actual observations or experiences. It is a text book as per the BCom I ${ }^{\text {st }}$ Semester syllabus of MG University, Kottayam. A syllabus oriented book has got it's own limitations. The author has referred mainly the books of Philip Kotler, the marketing guru. Many other printed and e-resources are also used to get inference on the topics covered. It fulfils the minimum requirements for appearing the University examination with confidence.

It is an effort of almost four years of handling the topic for UG courses. The book needs updates with more living examples. Hope the readers can suggest modifications.

The E-Book intended for free circulation, though priced. The print version, if required cannot be given without covering the cost of book and distribution. Hope this book will cater your examination requirement in an easy manner.

Boby Thomas

26/06/2019. 


\section{Contents}

1. Marketing Mix 1

2. Product Mix 30

3. Price Mix 54

4. Physical Distribution Mix 66

5. Recent Trends in Marketing 87

Index $\quad$ i

Bibliography v 


\section{Module I}

\section{MGU Syllabus}

Marketing Management-Market and Marketing- MeaningDefinition of marketing- Marketing Concepts - Marketing environment- Functions of marketing-Marketing ManagementMarketing Mix-4Ps and 4Cs- Importance of marketing mixFactors affecting marketing mix- Market Segmentation - Concept - Need - Basis-benefits- Market Targeting- Market Positioningdifferentiated and undifferentiated marketing

\section{Module II}

Product Mix- Product - Meaning- Classification of products- Product Line and Product Mix-New Product development- StepsReasons for failure of new products- - Product Life Cycle- Branding Types of brand- Brand Equity- Brand Loyalty- Trade Mark- Packaging-Role of packaging- Essentials of good packaging- Product Labelling- Marketing of services- Pricing of Products- Factors Influencing Pricing- Pricing Policies and Strategies -Types of Pricing

\section{Module III}

Price Mix - Pricing-Factors affecting pricing decision- Role of pricing in marketing strategy- Steps in formulating pricing- Pricing methods and strategies- Pricing of a new product- Resale Price Maintenance

\section{Module IV}

Physical Distribution Mix- - Logistic and Supply Chain Management - Elements- Channels of Distribution -TypesFactors Affecting the Choice of a Channel of DistributionFunctions of various Intermediaries - retailing- Types of retailingDirect Marketing- Merits and demerits

\section{Module V}

Recent Trends in Marketing (Overview Only)-Relationship Marketing - Social Marketing -Online Marketing- -Green Marketing-Tele Marketing -Viral Marketing- Relationship Marketing-De-marketing, Remarketing- Guerilla marketing - Ambush Marketing. 


\section{Module I}

Marketing Management-Market and MarketingMeaning- Definition of marketing- Marketing Concepts - Marketing environment- Functions of marketingMarketing Management- Marketing Mix-4Ps and 4CsImportance of marketing mix- Factors affecting marketing mix- Market Segmentation - Concept - Need - Basis-benefits- Market Targeting- Market Positioningdifferentiated and undifferentiated marketing

(12 Hours)

\section{MARKET}

The term market is derived from the Latin word "Marcatus" which means a place where trade (buying and selling) is conducted. Thus the traditional or general meaning of Market is a place where buyers and sellers meet together. In economics and business the term 'market' is defined as the sum total of all the buyers and sellers in the region for a particular good or service. The term market refers to the total demand of the potential buyers for a product. It is also used as a synonym to 'price' of a commodity, since the price is determined by market forces.

\section{MARKETING}

Philip Kotler defines marketing as "the science and art of exploring, creating, and delivering value to satisfy the needs of a target market at a profit. 
Marketing identifies unfulfilled needs and desires. It defines, measures and quantifies the size of the identified market and the profit potential. It pinpoints which segments the company is capable of serving best and it designs and promotes the appropriate products and services."

\section{MARKET VS MARKETING}

1) Meaning:

Market is a place where buyers and sellers meet each other for trade.

Marketing is a function that identifies the needs and products that satisfies them.

\section{2) What is it?}

Market is a place.

Marketing is a set of processes, i.e. a means of creating utility.

\section{3) Process:}

Market is a process, to the price through demand and supply forces.

Marketing is a process that analyses, creates, informs and delivers value to the customer.

\section{4) Concept:}

Market is a narrow concept.

Marketing is a wide concept that includes diverse activities. 


\section{5) Consistency:}

Market varies by products, place, factors, and so on. Marketing philosophy remains same, no matter where it is applied.

\section{6) Facilitates:}

Market facilitates trade between parties.

Marketing facilitates link between customer and company.

\section{Difference between Marketing and selling}

Point of difference Marketing $\quad$ Selling

1. Starting point 1. Consumer 1. Goods/Service

2. Focus 2. Customer needs 2.Existing products

3. Means 3. Integrated marketing

3. Selling \& promoting.

4. Aim 4. Profit through sales

4. Profit through customer satisfaction.

5. Importance 5. Product 5. Consumer.

6. Scope 6.Wider 6. Narrow.

7. Creation of utility 7. Only form, place, time, procession and information ${ }^{1}$ utilities

7. Time, place, and possession utilities.

${ }^{1}$ information utility: (1) A service bureau that maintains upto-date databases for public access. And (2) A central source of information for an organization or group. 


\section{Marketing Management}

"Marketing Management is the process of planning and executing the conception, pricing and promotion and distribution of goods, services and ideas to create exchanges with target groups that satisfy customer and organizational objectives."

\section{Philip Kotler ${ }^{2}$}

"Marketing management is the art and science of choosing target markets and getting, keeping, and growing customers through creating, delivering, and communicating superior customer value" Kotler and Keller, 2008: 5).

"Marketing management is the process of planning and executing the conception, pricing, promotion and distribution of ideas, goods and services in order to create, exchange and satisfy individual and organisational objectives"

American Association of Marketing

Thus marketing management includes planning for new product development, advertising and sales promotion to create, and retain the customers of the target market.

\footnotetext{
${ }^{2}$ born in Chicago, Illinois, this renowned author has been the International Marketing chair holder at Northwestern University since 1988
} 


\section{Marketing Concept}

The marketing concept is the strategy that firms implement to satisfy customer's needs, increase sales, maximize profit and beat the competition. They are philosophies which guide the business men in marketing efforts. There are five marketing concepts that organizations adopt and execute: Production Concept, Product Concept, Selling Concept, Marketing Concept, and Societal Marketing Concept.

1) Production Concept:

As per this concept, consumers will favor products that are available and highly affordable. This concept is one of the oldest Marketing management orientations that guide sellers.

\section{2) Product Concept:}

The product concept holds that the consumers will favor products that offer the most in quality, performance and innovative features. Under this concept, marketing strategies are focused on making continuous product improvements.

\section{3) Selling Concept:}

The selling concept holds the idea- "consumers will not buy our products unless we undertake a largescale selling and promotion effort". Here the focus is on increasing sales and not on building long-term, profitable customer relationships. 


\section{4) Marketing Concept:}

As per this concept organizational goals can be achieved only by knowing and satisfying the needs of the target market. Here the approach is "customer first". Under this approach customer focus and value are the routes to achieve sales and profits.

\section{5) Societal Marketing Concept:}

It holds "marketing strategy should deliver value to customers in a way that maintains or improves both the consumer's and society's well-being". It calls for sustainable marketing. Socially and environmentally responsible market will meet the present needs of consumers and businesses while preserving for future generations' needs. The Societal Marketing Concept puts the Human welfare on top before profits and satisfying the wants.

\section{Marketing environment}

The Marketing Environment includes the internal factors (employees, customers, shareholders, retailers, suppliers, distributors, etc.) and the External factors (political, legal, social, technological, economic, etc.) that surround the business and influence its marketing operations. According to Philip Kotler, marketing environment consists of the task environment and the broad environment. 


\section{(1) Task environment:}

It includes the immediate actors involved in producing, distributing, and promoting the product/service. They include company (management, employees), suppliers (material suppliers, marketing research agencies, advertising agencies, banking, insurance, transportation, telecommunication, etc.), dealers (agents, brokers, manufacturer, representatives, etc.), and the target customers.

\section{(2) Broad environment:}

It includes demographic, economic, natural, technological, political, legal, social, cultural environments.

\section{Functions of marketing}

Marketing is an essential process to the success of business. It involves researching, developing packaging and presenting products and services to consumers. Thus the functions of marketing include:

\section{Research}

One of the major functions of marketing is to conduct your research on the target market. Pay attention to the buying trends. Look for products that fulfill a current need. Market research also requires checking out competitors. It helps to find out what products they are featuring and how successful their marketing campaigns in the past. 


\section{Product Designing and Development:}

Product designing includes decision related to the quality, design of the product, packing, etc. This helps to make the product attractive to the target customers. For example, product designing for a color television includes shape, size, quality standard, technology etc.

\section{Pricing}

Pricing plays an important role in determining market success and profitability. Low price competition can be overcome by differentiating the product from competitors.

\section{Packaging}

Logos and packaging materials must all be designed with the customer in mind. Conduct market research to find the prototypes that receive the most positive feedback from test markets. Another function of marketing involves pricing your product at a rate where your business makes a profit.

\section{Transportation}

Transportation means physical movement of goods from the place of production to the place of consumption. How you deliver your products has a direct effect on marketing campaigns. For instance, you may advertise same-day shipping on all in-stock orders. 


\section{Risk Assessment and Quality Control}

Risk assessment entails looking at the variables that could affect the sale of your product or service. Quality control means looking at how your product stands up against the competition. It also involves meeting standards for product grading in applicable markets.

7. Some authors are of the opinion that marketing involves financing, insurance, and standardization, etc. are also the functions of marketing, since it has an impact on the success of business.

\section{Marketing Mix-4Ps and 4Cs}

Marketing mix is the combination of factors that can be controlled by a company to influence the consumers to purchase its products. The marketing mix is associated with the 4P's of marketing, the 7P's of service marketing, and the 4 Cs theories developed in the 1990s.

4 P's of marketing ("Four P Formula"): Product, Price, Promotion, and Place.

7 Ps of Marketing ("Seven P Formula"): product, price, promotion, place, people, Process and Physical evidence.

4 Cs theories: Customer/consumer value, Cost, Convenience, and Communication. 
1. Product: A product is an item that is built or produced to satisfy the needs of a certain group of people. The product can be intangible or tangible. It can be in the form of services or goods. A product has a certain life cycle - Introduction phase, growth phase, the maturity phase, and decline phase.

2. Price: Price of the product is basically the amount that a customer pays for to enjoy it. When setting the product price, marketers should consider the perceived value of the product. There are three major pricing strategies, and these are: Market penetration pricing, Market skimming pricing, Neutral pricing.

3. Promotion: Promotion can boost brand recognition and sales. Promotion is comprised of various elements like Sales Organization, Public Relations, Advertising, Sales Promotion, etc.

4. Place: Placement or distribution is a very important part of the product mix definition. Position and distribution of the product must be in a place that is accessible to potential buyers. There are many distribution strategies, including: Intensive distribution, Exclusive distribution, Selective distribution, Franchising, etc.

5. People: People include both the customers in the target market and employees of the company including management. There should be sufficient customers in the target market who are interested in 
the product. Employees are important because they are dealing with the customers. Management is most important since it has a direct influence on both customers and employees.

6. Process: Process is the flow of providing service to the clients. It includes measurement and monitoring of service, for customer satisfaction.

7. Physical evidence: It relates to the area where company representatives and the customer interact. Considerations include furniture, signage, and layout. It also pertains to how a business and it's products are perceived in the marketplace.

- Cost or price is the capital required to satisfy a customer's wants or needs. It includes the cost to release a new product or service to replace the old one. Opportunity cost is also part of the cost of product ownership.

- Consumer wants and needs drive the market for a product or service. A company should only sell a product that addresses consumer demand. So, marketers and business researchers should carefully study the consumer wants and needs.

- Communication includes feedback and responses from the customer with the goal of creating an ongoing dialogue. Marketers should aim to create an open dialogue with potential clients based on their needs and wants. 
- Convenience of place refers to the ease and the method in which the customer interacts with the company. The product should be readily available to the consumers. Marketers should strategically place the products in several visible distribution points.

\section{Importance of marketing mix}

The heart of your business success lies in its marketing. The marketing mix is a significant tool for creating the right marketing strategy and its implementation. "Marketing mix" is a concept used by business owners, marketing executives and operations managers to describe the essential elements of a marketing strategy. Marketing mix is the combination of factors that can be controlled by a company to influence the consumers to purchase its products. The marketing mix is associated with the 4P's of marketing, the 7P's of service marketing, and the 4 Cs theories developed in the 1990s.

Marketing mix helps in:

1. Optimum and effective utilization of economic resources.

2. Examination of the cost-benefit evaluation on the marketing of the product.

3. Facilitates effective communication

4. Facilitates the fixing of optimum price for the product. 
5. Facilitates management of customers, employees and other networks.

6. It facilitates effective distribution of products.

\section{Factors affecting marketing mix}

Marketing mix is a combination of factors that can be controlled by a company to influence consumers to purchase its products.

1. Nature of Product: Marketing mix is influenced by the nature of goods. For example, packing of hand wash is different from packing of toilet soap. Branding of durable items and FMCGs are different. Pricing of luxurious goods and general utility goods are different. Consumer goods are made available everywhere, whereas industrial goods are not. Heavy advertisement is made for Consumer goods. But promotion methods of industrial goods are different.

2. Stages of product cycle: Introduction, growth, maturity and decline are the four stages in the product life cycle. A company has to adopt different marketing mix at each of these stages. For example penetration pricing and price skimming are the 2 strategies designed for various stages.

3. Finance: Finance and budget of the company has an impact on the marketing mix. Some 
companies may not be able to provide much on the promotion mix.

4. Competition: The nature of competition has a great role on the marketing mix. If there is more competition, the firm may not be able to increase the price. Moreover it may compel to increase the cost of promotion mix.

5. Govt. Controls. Legal environment of the nation may influence the marketing mix of certain products. For example promotion of tobacco and alcohol products are banned in India. Govt taxes and availability of subsidies will also affect the mix.

6. Technological base of the company and market: The promotion mix is also affected by the nature of customers and their adaptability to technology. For example a product targeted for the youth can be promoted to social media.

\section{MARKET SEGMENTATION}

\section{(MICRO MARKETING)}

Philip Kotler : "Market Segmentation is the act of dividing a market into distinct groups of buyers who might merit separate products and/or marketing mix." 
Kotler and Armstrong: "Market segmentation is dividing a market into distinct groups of buyers who have distinct needs, characteristics, or behaviour and who might require separate products or marketing mixes"

Cundiff \& Still : " Market segments are grouping of consumers according to such characteristics as income, age, degree of urbanisation, race, or either classification, geographic location or education "

R.S. Davar: " Grouping of buyers or segmenting the market is described as market segmentation".

\section{Concepts of Market Segmentation}

1. Market is divided into different groups.

2. The basis of segmentation can be Geography, Demography, Culture, etc.

3. Heterogeneous market is divided into homogeneous market.

4. It narrows down the larger market into small accessible segments.

5. It is a customer-oriented philosophy

6. The basic aim is to identify the specific needs of different types of customers.

7. Market segmentation leads to STP-Segmenting, Targeting and positioning. 


\section{Need \& Importance (Benefits)}

of market segmentation

1. Customer needs, Preferences, behaviour and resources are different.

2. Segmentation helps to group homogeneous buyers.

3. It helps to analyse the nature and degree of competition.

4. Segmentation helps micro marketing.

5. It helps to design differential product to satisfy customer needs.

6. It helps to explore new markets.

7. It enables better positioning of products.

8. It helps to formulate strategies for promotion of products.

9. Segmentation aids in the implementation of marketing concepts.

10. According to Dr. Phillip Kotler, segmentation is the key to good marketing.

11. It helps to eliminate wastage of time, and money, to both marketer and customer.

12. It helps to choose the advertising media more wisely.

13. It helps to determine the timing of the advertising efforts. 
14. It helps the manufacturer to face the competition effectively.

15. It narrows down the larger market into small accessible segments.

16. Market segmentation leads to STP-Segmenting, Targeting and positioning.

\section{Bases for Market Segmentation}

There are many ways by which a market can be segmented. But methods of market segmentation will vary from product to product. Market can be broadly classified into two types i.e., consumer market and Industrial market. Consumer market consists of ultimate users who normally buy in smaller quantities. Industrial market, on the other hand, consists of industrial users who make bulk purchases for the purpose of converting them into final products.

$\underline{\text { Segmentation of consumer markets }}$

According to Philip Kotler, consumer market can be segmented on the basis of four variables Geographic, Demographic, Psychographic, and Buyer behaviour. These bases are called segmentation variables.

\section{Demographic variables or socio - economic variables}

Demographic variables are the most popular bases for segmenting consumer markets. 
1) Age: Consumer wants and capacity to buy differs with age. The manufacturer should see to which age group, his product would be most suitable because only on the basis of age group of customers.

2) Sex; Many products have been traditionally purchased by one sex or the other. Females purchase cosmetics. But shaving blades are purchased by males.

3) Income: Income is the main source of purchasing power. People with money to spend only can make a market.

4) Education: On the basis of level of education, consumers can be classified into literate, illiterate, educated and uneducated.

5) Religion: Religion influences the buying behaviour, motivation and timing of purchase.

6) Occupation: Occupation, which is the source of income for an individual, may also affect the buying behaviour.

7) Family Size: Size of family is another criteria, which may affect the segmentation for certain products like almirah, dining table sets, pressure cookers, etc. 


\begin{tabular}{|c|c|c|c|}
\hline Demographic & Geographic & Psychographic & Behavioral \\
\hline $\begin{array}{l}\text { Age/Life } \\
\text { Cycle } \\
\text { Gender } \\
\text { Family size } \\
\text { Occupation } \\
\text { Income } \\
\text { Education } \\
\text { Social class } \\
\text { Religion \& } \\
\text { Culture } \\
\text { Ethnic } \\
\text { group/ } \\
\text { Race/ } \\
\text { Nationality }\end{array}$ & $\begin{array}{l}\text { Regions - } \\
\text { nations, } \\
\text { states, } \\
\text { taluks, } \\
\text { villages, } \\
\text { Density - } \\
\text { cities, } \\
\text { urban, } \\
\text { semi urban, } \\
\text { rural } \\
\text { Climate - } \\
\text { Hot. } \\
\text { Cool } \\
\text { Humid } \\
\text { Rainy }\end{array}$ & $\begin{array}{l}\text { Attitudes } \\
\text { Interests and } \\
\text { Opinions } \\
\text { values } \\
\text { lifestyles } \\
\text { personality } \\
\text { reference } \\
\text { groups } \\
\text { social role/ } \\
\text { status }\end{array}$ & $\begin{array}{l}\text { Occasions- } \\
\text { festival, wedding, } \\
\text { beliefs } \\
\text { Decision Roles: } \\
\text { Initiator } \\
\text { Influencer } \\
\text { Decider } \\
\text { Buyer } \\
\text { User } \\
\text { User status- } \\
\text { nonusers, ex-users, } \\
\text { potential users, } \\
\text { first-time users, } \\
\text { regular users } \\
\text { Buyer Readiness- } \\
\text { unaware, aware, } \\
\text { informed, } \\
\text { interested, desire, } \\
\text { intend to buy. } \\
\text { Attitude- } \\
\text { enthusiastic, } \\
\text { positive, negative } \\
\text { indifferent, } \\
\text { BenefitsExpected- } \\
\text { quality, economy, } \\
\text { urgency, flexibility } \\
\text { Brand loyalty } \\
\text { Price } \\
\text { consciousness }\end{array}$ \\
\hline
\end{tabular}




\section{Geographic Variables:}

On the basis of area, a product market can be segmented into different geographical units like nations, states, regions, countries, cities, urban, rural, climatic conditions like hot, cold, humid, etc.

On the basis of population density market can be segmented as urban, semi-urban, rural and remote. Marketing strategies are to be prepared by considering the characteristics of each and every market.

\section{Psychographic Variables:}

In Psychographic Segmentation, segments are defined on the basis of social class, lifestyle and personality characteristics. A segment having demographically grouped consumers may have different psychographic characteristics.

Life style: clothing, bags, shoe, umbrella, etc school going, college going, office going or other. Thus by lifestyle we mean, where does the customer stand in his life cycle. (conservative, trendy, economical)

Value Segments: Innovative system of market segmentation goes beyond demographics and psychographics. They explore the values, mindsets and attitudes that motivate consumer behaviour.

Eg. (Money is for spending not saving), Save for next generation, Conventional Family Life Segment, 
Young Optimism Segment (New experiences and personal fulfillment), provide their family with the best in life,

AIO (Activities, Interests and Opinions) dimensions

Attitudinal segments: Towards Chinese product, fast food, attitudes and beliefs (health conscious, environmentalist, security conscious, etc.)

Interest and opinions: hobbies, weekends, holidays,

Opinion: political party or movie marketer -will say that audience opinion is one of the topmost factors affecting the rise or fall of a political party or a movie.

\section{Behavioral Variables :}

Behavioral variables are the best starting point for constructing market segments. In behavioral segmentation, consumers can be divided into groups on the basis of their attitude, user status, knowledge, expectation from the product, usage rate, usage habits, benefits expected, brand loyalty, etc.

\section{MARKET TARGETTING}

Market targeting is a process of taking decision regarding the market segments to be served. The term Target market' means, "a group of customers(Segment) at whom the organisation specially aim its market effort". The term Target 
marketing' means developing tailor made products and programmes to two or more selected segments. Eg. Horlick has segmented the market on the basis of age groups and formulated strategies accordingly: Junior horlicks- for preschool children, Horlicks regular- for general use, Women's horlicks-for pregnant and breast feeding women, Horlicks Litefor health conscious adults and for diabetic people, and Chocolate and other flavored horlicks- for teenagers

\section{Advantages of Target Marketing}

1. Marketing efforts can be concentrated on the market segments which offer the greatest potential for the company to achieve its goals.

2. It is particularly suitable in case $f$ services.

3. Marketing opportunities may be accurately identified.

4. It puts all the efforts on one or two segments selected.

5. Marketing opportunities may be accurately identified.

\section{Steps in Market Targeting}

Market Targeting consists of two steps:

(1) Evaluating the market segments, and

(2) Selecting the market segments. 


\section{Evaluating the Market Segments:}

In evaluating the different market segments, the firm must look at three factors, namely - Segment size and growth, Profitability, Segment structural attractiveness (competitor, customer, substitute, etc.) and Company objectives and resources.

\section{Selecting the Market Segments:}

Having evaluated the market segments company should now decide how many segments to serve. There can be of 5 patterns of selection: single segment, multi-segment strategy, Product Specialisation, Market Specialisation, and Full Market Coverage.

\section{Developing the products:}

Products may be developed and designed as to cater the specific needs of the segment selected. For example, Kinder Joy is developed to cater the specific needs like, sweet, toy and curiosity in a single product.

\section{MARKET (PRODUCT) POSITIONING}

Positioning refers to 'how organisations want their consumers to see their product'. Positioning is all about 'perception'. It is a marketing strategy that aims to occupy a distinct position, relative to competing brands, in the mind of the customer. It is 
a battle to conquer the minds of target market. It differentiates the product to create a value. The goal is to create a unique impression in the customer's mind so that the customer associates something specific and desirable with your brand that is distinct from rest of the marketplace. Eg. lowest price, best service, freshest product, 24hour service, easy access, etc.

Positioning $=$ Differentiation + Segmentation .

\section{Elements of Positioning}

Positioning is a combination of the three elements:

(a) Attributes (Characteristics): Shape, colour

(Ujala super white), price (Parker pen), durability (V Guard), etc.

(b) Product communication: How the product is communicated in the target market. (Ujala songs)

(c) Perception: How the consumers perceive a product compared to other competing brands.

\section{Market Positioning Strategies.}

1. Positioning by product benefits: The benefit of the product is focused.

Eg. Colgate for strong teeth.

2. Positioning by price: The price will be either high or low compared to competitor.

Eg. Parker pen. 
3. Positioning by user: Here the major user of the product is focused. Eg. Kinder joy for fun for kids, Holicks for stronger, taller, sharper boy.

4. Positioning by Usage/Application: Here the product is introduced as a item for specific usage. Eg. Surf Exell as stain remover, Vicks vaporab as relief of cough and nasal congestion.

5. Positioning by product class: Here the product is introduced as luxurious class. Eg. Apple phones, Jaquar taps \& showers, Titan Nebula are positioned as superior class; whereas Titan Sonata is positioned as economy.

6. Positioning by competitor: Comparative benefit against competitor is focused. Eg. Harpic toilet cleaner, Airtel 4G network,

7. Positioning by cultural symbols: It is a positioning strategy where in the cultural symbols are used to differentiate the brands. Eg. AirIndia's 'Maharaja'(King of India), Patanjali products as catering to Indian tradition, Matrimonial sites.

\section{DIFFERENTIATED MARKETING}

It is a strategy in which several market niches (or population segments) are targeted with different products for each niche or segment.

For eg. Titan company has different brands like Titan, Sonata, Fastrack, SF, Xylys, Nebula, etc. 


\section{UNDIFFERENTIATED MARKETING}

Marketers use the same message for all segments of the market, in an undifferentiated marketing strategy. This is similar to mass marketing. Marketers typically create a message that appeals to everyone, so the message is often general or simple to allow more people to relate. For eg. A hotel may introduce itself without any segmentation. Eg. advertisements of TV, laptops, household durables, FMCGs, etc

\section{Product Differentiation:}

Marketing of generally similar products with minor variations that are used by consumers is called product differentiation. Under this, the marketer produces, two or more products that are different in terms of features, styles, quality, size and so on. The objective is to offer variety to buyers rather than to appeal to different market segments. Eg. Titan Sonata is available in more than 600 designs, Alto 800 is available in three variants and six colors - Std, lx \& 1xi.

Diary milk has 12 differentiated products: Diary milk (ordinary), silk, bubbles, fruit \& nut, cracker, pista, almond, caramel, cashew \& coconut, oreo, liquiables and shots. 


\section{Mass Marketing}

1. Assumption: Customers have similar needs and wants and can be satisfied with a standardized product/service offering.
2. Standardized product is produced and distributed with a single marketing program or the same marketing mix.

\section{Market Segmentation}

1. Customers are unique:They have different needs, wants and preferences. There exist diverse customer groups homogenous on certain bases within, but heterogeneous among each other.

2. So, instead of a single standardized product offering, the product and service offerings are designed according to the needs and wants of the segment so as to satisfy them better.

3. Leads to higher customer satisfaction distribution: Lower costs; Results in lower prices and higher margins.

4. Also called mass marketing, aggregate marketing and undifferentiated marketing.
4. It has various forms:

Single Segment, Differentiated segment, Concentrated segment or Niche, Micro-marketing: local, individual. 


\section{Concentrated Marketing Individual marketing} $\underline{\text { (Niche) }}$

1. Marketer caters to just one segment although the product could appeal to others.

2. The process includes targeting a small segment with a specialized mix meant only for that segment.

1. The marketers cater to the customer individual and personalize the marketing mix.

2. The segment comprises one individual; So it is individual to individual marketing.

3. Also called focused or niche marketing.

3. Also called customization

4. Example:

4. Example:

Sports channels on TV; Holiday packages

Religious channels on TV.

\section{Review Questions}

\section{Two Mark Questions}

1. What is meant by market?

2. Define 'Marketing Management'?

3. Differentiate Market and Marketing.

4. What is product positioning?

2014, 2015

5. What is target marketing?

$2010,2011,2014$

6. What is meant by STP?

7. Explain marketing concepts. 


\section{Mark Questions}

8. Explain segmentation 2010, 2012,2015

9. What do you mean by buying motives? 2015

10. What is demographic segmentation?

11. What are the steps in the process of market segmentation?

12. Define C.B. (Consumer Behaviour)

13. Describe the importance of market segmentation?

14. What are the strategies of market positioning?

\section{Mark Questions}

15. State and explain the essential condition of successful market segmentation?

16. Explain the basis of market segmentation.

17. Explain the functions of marketing. 


\section{Module II}

Product Mix- Product - Meaning- Classification of products- -Product Line and Product Mix-New Product development- Steps- Reasons for failure of new products- - Product Life Cycle- Branding Types of brand- Brand Equity- Brand Loyalty- Trade MarkPackaging-Role of packaging- Essentials of good packaging- Product Labelling- Marketing of servicesPricing of Products- Factors Influencing Pricing- Pricing Policies and Strategies -Types of Pricing

Product is a commodity or service to satisfy the needs of the people. A product is a good, idea; method, information, object or service created as a result of a process and serves a need or satisfies a want.

"A Product is anything that can be offered to a market for attention, acquisition, use or consumption that might satisfy a want or need. It includes physical objectives, services, persons, places, organisations and ideas."

Philip Kotler

\section{Features of Product:}

1. Capacity to fulfil the needs of people.

2. It can be a tangible commodity or a service.

3. It can satisfy both commercial and personal needs. 
4. It is the subject and object of all marketing activities.

5. It is a collection of tangible and intangible features.

\section{Types of Product}

\section{Industrial Products:}

Goods used for the production of other goods are called industrial products. Eg. Machineries, raw materials, tools, etc.

\section{Consumer Products:}

Goods used by the ultimate consumers are called consumer products. Eg. Food items, cloth, tv, computer, medicines, etc.

\section{Types of Consumer Products}

1. FMCGs - Fast Moving Consumer Products. Eg. Soap, tooth paste, pen, soft drinks,

\section{Consumer Durables.}

- White Goods: Refrigerators, washing machines, a/c.

- Brown Goods: TV, Computer, DVD players, mobile phones.

- Soft Goods: Dress items, window curtains, other fabric items.

3. Convenience Goods: Fast foods, tin foods, pen, pencil 
4. Perishable Goods: Meat, fish, milk, butter, ice cream

5. Shopping Consumer Goods: Textiles, foot wares, jewellery

6. Speciality Consumer Goods: Diamond, gold, costly dress materials

7. Unsought Consumer Goods: Medicines, coffins

\section{Product line}

Product line is a group of products that are closely related to each other. It is a set of products related to each other. For eg. The product line of Dabur India includes Home care, Heath care, Skin care, oral care, hair care and baby care.

\section{Product}

Product is an individual unit within the product line. For eg. Dabur India's babool 100 gm, dabur chyawanprash 500 gm, etc.

\section{Product mix}

Product mix is the full list of all products offered for sale by a company. It consists of both product lines and individual products.

\section{Dimensions of Product Mix}

- Width: The number of product lines.

- Depth: The number of varieties of each products in a product line. 
- Length: Total number of products within all product lines.

- Consistency: Close relativeness of product lines. The ability to flow through a single distribution channel.

For eg. a company has 4 product lines. Each product line offers 3 products each. Then, width of the product mix is 4 . Depth of the product mix is 3 . Length of the product line is 12 .

\section{Product development}

Product development is an attempt to design the product. It includes developing new products and modifying existing product.

\section{Need for Product Development}

a) Customisation of Product: Customization helps to deliver a wide-market goods and services to satisfy a specific customer need. Product customization helps brands boost sales.

b) Adjust with Product Life Cycle: All products move through a product life cycle. The product life cycle contains four distinct stages: introduction, growth, maturity and decline. NPD helps to cope with this product life cycle.

c) Innovation: NPD facilitates innovation of new products and services. 
d) Fighting Competition: NPD helps to cope with competition. Innovative products will attract more and more customers

e) Improving Brand Loyalty: If a company introduces innovative products, it will boost up the brand and brand loyal customers.

f) Increasing Market Share: Increased innovations will help the company to increase their market share.

Stages of New Product Development (Product Development Process)

Product idea and product design are the most important aspects of new product development.

1. Idea Generation: The first step is to generate an idea for the product. Requests from customers, feed-back from customers, brainstorms with employees, responses to a competitor's product, or suggestions on social media, etc. can be used as a base for generating idea.

2. Idea Screening: Make a list of product ideas. Discuss the pros and cons of each idea. Analyse their potential to generate revenue, under the planning premises. Narrow the list to just a handful of the best ideas.

3. Product design: With the help of 3D modelling software (CAD - Computer Aided Design), develop a computerized 3D model of the absolute product design. A product design needs to take 
into account how the item will perform its intended functionality in an efficient, safe and reliable manner. The product also needs to be capable of being made economically and to be attractive to targeted consumers.

4. Concept Testing: Once we've developed a sample of the product or service, it should be tested with customers. This can be done in formal focus groups of customers and informally by testing it with existing customers.

\section{Prototype Development}

Create a fully functional physical model of the product. A physical model is the best option for testing product features.

\section{Prototype Testing and Feedback}

Test the product prototype with family, friends, and potential financiers. Listen to the feedback and modify the design if necessary.

7. Product creation: Once satisfied with the performance of product prototype, proceed to the manufacturing stage.

8. Business analysis: It includes forecasting market size, estimation of production cost, profits, etc. Customer survey, distributor survey, competitor analysis, raw material availability, finance, manpower, legal standards, reputation of the company, etc. are also analysed in this respect. 
9. Product and Marketing Mix: It involves design and development of the sample product. The real product is designed with clear size, shape, colour, name, trademark, packaging, etc. Distribution channel, warehousing, order processing, etc. are decided. Promotion mix like advt., publicity, sales promotion, discount, pricing strategies, retailer margin, etc. are also fixed at this stage.

10. Test Marketing: Means experimental marketing of goods in limited geographical area. The objective is to determine the commercial viability.

11. Launching the new product: Commercial production and launching of new product is done after considering the timing of launching the product.

12. Post Launch analysis: Objective is to analyse the performance of the new product in the market. It helps to analyse the strength and weakness of the product.

\section{Reasons for failure of new products}

1. Lack of product uniqueness: Any product that does not satisfy a unique need of consumers, fails to dislodge more established brands available. A product is likely to be perceived as unique if it satisfies a new function; if it satisfies an existing function in a new ways; if its price and 
performance give it an advantage over the competitive products. It should be distinctive in one way or the other.

2. Poor planning: Life- styles changes, age and preferences changes, technological advance and many other forces alter consumer's needs and wants for products. Companies must have a game-plan that at every stage and aspect of product's life. The plan is to care for consumers.

3. Poor timing: The market success depends, to a large extent, on the ability of the company to launch the product at a time when consumer demand is at its highest. Hence, appropriate time has its strategic importance in product success.

4. Misguided enthusiasm: On several occasions, there will be either an under-estimation of the strength of competitors or an over-estimation of one's own capabilities resulting in over-optimistic calculations. This will affect the actual product performance in the market.

5. Product deficiencies: Many a times, technical product deficiencies are the common cause of new product failure. Bad design, poor user experience, sloppy implementation, feature creep, and lack of quality control all contribute to product failure.

6. Targeting the Wrong Market: It's hard to know how the market will react to a product and 
marketing messaging. If the customer finds no reason to shift from the existing brand, the product may become failure. Eg. 'Zune' an iPod launched by Microsoft, in 2006 offered everything that was offered by Apple. Yet it failed. Microsoft admits that they were just chasing Apple and created a product that offered no reasons for customers to switch.

7. Fixing a Non-Existent Problem: If the product failed to satisfy an existing need by its utility, the product may tend to fail. For eg. In 1990 Maxwell House launched Ready to Drink Coffee. But the product was not ready to drink as promised. Instead it took the same time to make it ready for drink. Hence the product failed.

8. Lack of Financial return: About 30 to $45 \%$ of new products fail to deliver any meaningful financial return. This typically happens due to a number of reasons, from poor product / market fit, failure to understand customer needs (or fixing a non-existing problem), to a lack of internal capabilities.

\section{Product Life Cycle}

The product life cycle is the different stages in the sales story of a product. They are introduction, growth, maturity and Decline. The original product will be replaced by new innovative product after some time. 
Eg. $\quad$ Pencil $->$ fountain pen $->$ ball point pen

Type writer $->$ Electronic type writer $->$ Computer

Floppy Disk -> CD -> DVD -> Pen Drive

Radio -> Tape Recorder -> CD Player -> DVD Player-> USB portals

Land Phone -> STD Booth -> Coin box -> Mobile phone -> Smart phones

Film Camera -> Digital Camera-> Mobile ph camera B\&W TV-> Color TV->LCD TV, LED TV->Plasma TV

\section{Stages of PLC:}

(1) Product Development: It is the first stage where the product is developing. The company may provide information to the customers after developing the concept or at the time of trial run to the prospective customers. Eg. Flying cars of Google, i phone 7

(2) Introduction: This is the launching stage of a new product. Intense marketing efforts, trial purchase by customers, high cost of production, intense promotional measures, low sales, low profit, low competition, etc. are the features of this product. Eg. 4G data pack by idea in 2016 . Now it is in maturity stage.

(3) Growth: At this stage customers get awareness about the product as a result of the promotional 
measures. Reduction in cost, bulk production, increased demand, increased sales volume, increased profit, increase in competition, price stability, etc. are the features of this stage. PLC management at this stage includes improved quality, extra benefits, pricing, etc.

(4) Maturity: Sales reaches its maximum at this stage and the market attains saturation. Low cost, maximum sales volume, market saturation, intense competition, reduced price, etc. are the features of this stage. PLC management at this stage includes Product expansion, contraction, differentiation, Lower prices and promotional measures to meet competition.

(5) Decline: Last stage in the product life cycle is decline stage. This stage is characterised by heavy decline in sales volume, price and profitability, reduced marketing efforts, etc. PLC management at this stage includes high cut in prices, selling product to another company, withdrawal of product, innovation of new product, etc.

\section{Importance/Advantages of PLC model}

1. It helps the marketer to formulate adequate marketing strategies.

2. It helps to study past sales to forecast future sales. 
3. It helps to eliminate inactive products.

4. It helps in developing and improving new products.

\section{Criticism on (Disadvantages of ) PLC model}

1. PLC is only an assumption.

2. It is difficult to determine the various stages of PLC.

3. PLC consider the variations in sales, but not the reasons for variations.

4. PLC considers the relationship between sales and time. But it ignores the major factors like cost, price, competition, market conditions, etc.

\section{Branding}

Brand is a name, term, sign, symbol, design or any other feature that identifies one seller's goods or service as distinct from those of others. Eg. Ujala, Tata, Tata Docomo, V Guard, etc.

Branding is the process of creating a unique name and image of a product in the minds of the consumers. It aims to establish a significant and differentiated position for the product in the target market. Branding helps to attract and retain the customers.

\section{TRADEMARK}

Trade mark is the legal term for brand. A trademark is a registered brand or trade name. A Brand/Trademark is an intangible asset. 


\section{Importance of Trademark}

1. It gives legal protection to a brand.

2. It prevents unauthorised use of a brand.

3. It ensures quality of products to consumers.

4. Identification of trade mark and product becomes easy.

5. Trade marking gives more acceptance to brand.

6. It increases authenticity of a brand.

Logo: A logo is a graphic mark, emblem, or symbol commonly used by commercial enterprises, organizations and even individuals to aid and promote instant public recognition. Logo is the face of the company.
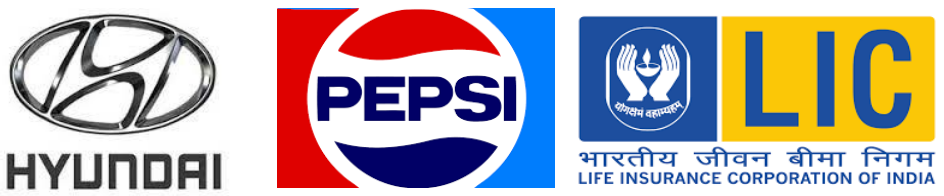

\section{Types of brand (Branding Strategies)}

1. Family Branding

2. Corporate Branding

3. Individual Branding 4. Combination Branding

\section{Family (Umbrella) Branding:}

Here Single brand name is used for the sale of two or more related products. A company may have several such brands. 
Eg. Titan, Sonata, Fastrack, Xylys, Nebula are family brands of Titan.

\section{Corporate Branding:}

Here brand name of a corporate entity is promoted rather than the products. All the products are given only the corporate brand.

Eg. Philips, Samsung, LG

\section{Individual Branding}

(flanker brands or multi branding):

Marketing policy under which each product has its own brand, different from every other product in the same product family or from the same firm.

Eg. Procter \& Gamble (P\&G), Jyothylaboratories,

Procter \& Gamble (P\&G): Vicks, Ariel, Tide, Whisper, Olay, Gillette, Ambipur, Pampers, Pantene, Oral-B, Head \& Shoulders, Wella and Duracell

Jyothi Laboratories : henko Stain Champion, Mr. White, Ujala, Ujala Stiff \& Shine, Ujala washing powder, Morelight, Chek \& Speed, Maxo, Exo, Henko, Pril, margo, fa

\section{Combination Branding:}

Brand name that emphasizes a corporate or brandfamily name as well as the product's brand name is called combination brand. It is the use of a combination of brand names. I.e. a corporate brand name and an individual brand name. 
Eg. Toyota Corolla or Honda Civic, Maruti, Hyundai...

Toyota Etios Liva, Etios, Etios Cross, Innova, corolla, fortuner, carmy, land cruiser

Maruti: Alto, Swift, Zen, Celerio, Swift DZire, SX4, Ciaz, Omni, Wagonr, Gypsy, Ritz, Eeco.

Brand Equity: Brand equity is a brand's power derived from the goodwill earned over time, which translates into higher sales volume and higher profit margins against competing brands. It may be reflected in the way consumers think, feel and act with respect to the brand. If the brand's equity is positive, the customers might buy its new product by associating the new product with the existing, successful brand.

\section{Assets underlying brand equity:}

1. Brand awareness: Consumer awareness of the brand. Eg. the brand VGuard is so popular in Kerala but not that much in north India. The brand 'Sony' is popular all over the world.

2. Product quality: The quality of the product to satisfy the needs of the consumer and his expectations. Godrej gives an impression of quality in safe lockers. 
3. Brand loyalty: Number of customers loyal to a particular brand. How likely a customer switches to another brand.

4. Brand Associations: The degree to which a particular brand is associated with the general product category. Consumer asks for the brand rather than the generic name. Eg. colgate, Closeup, Ujala, Pears,

5. Other assets: Patents, logo, package, Trademarks, channel relationships.

Brand Loyalty: Brand loyalty is the customer's devotion to a particular brand. Brand loyalty is resulted in repeated purchase and word of mouth promotion.

Patterns of Brand loyalty Philip Kotler

1. Hard-Core Loyals: Consumers who buy a particular brand all the time.

2. Split Loyals : Consumers who are loyal to two or three brands.

3. Shifting Loyals: Consumers who move from one brand to another.

4. Switchers: Consumers who have no loyalty to any brand.

Brand image: The general impression of a product held by real or potential consumers is called brand image. It is what the customers think about a 
particular brand. Brand image is the set of beliefs held about a particular brand. It may include real and imaginary qualities as well as shortcomings.

\section{Brand}

Mercedes Benz

Dettol

Poppy

Maruti

\section{Image (?)}

Luxury, Quality.

Antiseptic.

Quality umbrella.

Service everywhere.

\section{Product image:}

It is very similar to brand image. The perceptions and the mental image associated with the product are called the product image. Eg. Ujala, Dettol

\section{Packaging}

Packaging is the part of product planning which involves designing and producing the container or wrapper for a product. It is concerned with the protection, economy, convenience and promotional considerations.

\section{Role of packaging-}

1. Physical Protection from damage, contamination, climatic changes, etc

2. Containment as per the size and quantity.

3. Security during transportation

4. Convenience in storage, distribution, handling

5. Information on product, usage, recycle, disposal

6. Promotion to attract the attention of the customers. 


\section{Essentials of good packaging-}

1. Convenient: Package should be convenient for handling and storing.

2. Protective: Packaging should be capable of protecting the product.

3. Attractive: The package must be capable of attracting the attention of customers.

4. Economical: Packaging should not be costly to increase the cost of the product.

5. Communicative: Packaging should provide all information required as per the laws of the country. It should also provide adequate information to the user.

6. Eco friendly: Packaging should be made with ecofriendly materials.

\section{Product Labeling}

Labeling is describing something in a word or short phase. "Display of information about a product on its container, packaging or the product itself is called labelling." Branding, packaging and labeling are the secondary functions of marketing.

\section{Importance of labeling}

1. It provides information about the product.

2. It helps to identify the product and brand.

3 . It promotes the product.

4. It protects the customers by displaying its ingredients, MRP, quantity, etc. 
5. It protects the customers from the malpractice of middlemen.

\section{Types of label}

1. Brand Label

2. Price Label

3. Quantity Label

4. Barcode Label
5. Descriptive Label

6. Address Label

7. Date Label

8. Warning Label

\section{Marketing of services}

Service sectors account for more than $70 \%$ employment opportunities. Our economy is emerging as the service economy because service sector contributes more than 50 per cent to the GDP of the nation. India is experiencing a service boom. Notable growth rate has been recorded in many service sectors.

\section{Characteristics of services:}

- Lack of ownership.

- Intangibility.

- Inseparability.
- Variability.

- Perishability.

- User participation

Service sector includes insurance, transportation, telecommunication, IT sector, electricity, postal services, tourism, banking, health care, entertainment, education, consultancy, etc.

Philip Kotler: "A service is any activity or benefit that one can offer to another that is essentially 
intangible and does not result in the ownership of anything. Its production may or may not be tied to a physical product."

The American Marketing Association (AMA): Services are activities, benefits, or satisfactions which are offered for sale or provided in connection with the sale of goods."

\section{Pricing of Products:}

'Price is the exchange value of goods and services in terms of money.' Pricing means determination of selling price for a product or service.

\section{Objectives of Pricing}

1. Target return on investment.

2. Profit maximisation.

3. Price stabilisation

4. Increase in sales.

5. Maintain and increase market share.

6. Meeting competition.

7. Status Quo goals: Cheap/Premium goods.

8. Survival

\section{Factors Influencing Pricing-}

Factors influencing pricing:

(a) Internal Factors, (b) External Factors 


\section{A. Internal Factors}

1. Marketing Objectives

-M share, Competition, Survival

2. Cost of production

3. Cost of transportation.

4. Cost of distribution.

5. Cost of advertisement

6. Sales promotion

7. Marketing Mix strategy-Ps

\section{B. External Factors}

1. Demand for the product

2. Competition

3. Government Policy

4. Channels of distribution

5. Entry and Exit barriers in industry

\section{Pricing Policies and Strategies}

(Methods/Approaches of Pricing)

1. Cost Oriented Pricing Policy:

Total Cost + Fixed Profit \%. Eg. Busfare.

2. Demand Oriented Pricing Policy:

Focus on level of Demand. Not on cost.

Eg. Airline Pricing.

3. Competition Oriented Pricing Policy: 
Price fixed on the basis of competing firms.

Eg. price of FMCGs

\section{Types of Pricing}

1. Premium Pricing. 7. Promotional Pricing.

8.Geographical Pricing.

2. Penetration Pricing. 9. Differential Pricing.

3. Economy Pricing. 10. Going-Rate Pricing.

4. Price Skimming. 11. Monopoly Pricing

5.Image/Prestige Pricing. 12. Odd Pricing

6.Administered Pricing.

1. Premium Pricing: Shows the product is superior and unique.

Eg. Parker pen.

2. Penetration Pricing: Low price initially to capture the market and increase the price later. Used by late comers in the market.

Eg. Apple, Samsung, etc in smart phone segment, television cable co.s.

3. Economy Pricing: Keeping lowest price.

Eg. retail food business,

4. Price Skimming: Initially high price and later lowers the price. Eg. Audi car,

5. Image/Prestige Pricing: High price to keep the superior quality/social status. Eg. Titan xylys wrist watch, Linen club shirts 
6. Administered Pricing: Here price is fixed by a legal statute or by a regulatory body formed by the Government.

Eg. Petrol, public bus fare, etc.

7. Promotional Pricing: Here the pricing strategy is to promote the product.

Eg. 10\% Discount, 15\% Extra, Buy 3 get 1 free, etc.

8. Geographical Pricing: Here different prices are charged from the customers of different geographical area.

Eg. Price of petrol and diesel

9. Differential Pricing: It is the pricing strategy of selling the same product to different customers at different prices. Price changes according to time of purchase, season, etc.

Eg. Airline pricing.

10. Going-Rate Pricing: The product is priced as per the rates prevailing in the market especially on par with the competitors.

Eg. price of FMCGs

11. Monopoly Pricing: A firm with monopoly power sets a monopoly price that maximizes the Monopoly profit.

Eg. Windows, Adobe pdf.

12. Odd Pricing: Odd pricing refers to a price ending in $1,3,5,7,9$, just under a round number, such as ₹10.19, ₹ 5.56, ₹99.99. 


\section{Review Questions}

\section{Mark Questions}

1. What is product mix?

2. What is PLC?

3. What is a product?

2011

4. What is product mix?

5. What is product line?

6. Define Branding.

7. Explain Brand equity.

8. What is a Brand?

9. What is brand loyalty?

10.What is multi branding?

11.What is meant by brand image?

12.What is Test marketing?

13. What do you mean by trade mark?

\section{Mark Questions}

14. What are the classifications of products?

15. Explain the steps on New Product Development.

16. Explain the stages of Product Life Cycle.

17. What are the types of brand?

18. What are the contents of product label?

19. What is a 'pricing strategy'?

20. Explain the concept of service marketing.

21. Explain brand image.

\section{Mark Questions}

22. Explain the role of packaging in business.

23. Explain the factors influencing pricing.

24 . What are the types of pricing? Explain.

25. Explain the types of brands with examples. 


\section{Module III}

Price Mix - Pricing-Factors affecting pricing decisionRole of pricing in marketing strategy- Steps in formulating pricing- Pricing methods and strategiesPricing of a new product- Resale Price Maintenance

(12 Hours)

\section{Price}

According to Philip Kotler: "Price is the amount of money charged for a product or service." Price is the total amount exchange by the customer to obtain a benefit of the product or service. It is the amount of money expected, required, or given in payment for something. Pricing is deciding the amount required as payment for (something offered for sale).

'Price is the economic value of product expressed in form of money.'

'Price is the exchange value of goods and services in terms of money.'

\section{Price Mix}

Price mix is an important and critical element of marketing mix. There are price-sensitive customers and prestige-sensitive customers. Therefore Pricing decisions become vital in marketing. Pricing strategy should reflect product's positioning. Price should cover the cost per item and the profit margin. 
Price mix is the value of the product determined by the producers. Price mix includes the following decisions:

a) Price level to be adopted

b) Discount to be offered

c) Terms of credit to be allowed to customers.

\section{Elements of Pricing Decisions}

1. Product development costs

2. Manufacturing (variable and fixed) costs the product

3. Pricing policies and strategies of competitors

4. Formulating appropriate pricing policies for the products

5. Deciding margin of profits

6. Deciding pricing strategies such as variable v/s fixed pricing, price discrimination, discounts, allowances, and seasonal effect.

7. Identifying and analyzing of various factors influencing pricing decisions

8. Pricing policies/strategies in different stages of product life cycle

9. Deciding on price-setting methods

10. Pricing decisions for direct and indirect distribution of products 


\section{Pricing of Products:}

Pricing is one of the four Ps of the marketing mix. (Other three being Product, Promotion, and Place. Price is the only revenue generating element amongst the four Ps. Other Ps are cost centers. However, the other Ps of marketing will enable price increases to drive greater revenue and profits.

\section{Role of pricing in marketing strategy}

1. Pivot of economy: Pricing also determines standard of living. The lower the prices in the economy, the higher are the purchasing power in the hands of consumers. Price reflects purchasing power of the market. Price influence production, distribution and consumption. It influences the economic development.

2. Regulates Demand: Demand is influenced by change in price. Demand increases or decreases with decrease or increase in price. Demarketing is also possible through a price hike.

3. Weapon for Competition: Every company compares its price with that of its competitors. Pricing at any point in the life cycle is based on competition.

4. Target return on investment: Price determines the profitability of the business. Ensuring target return on investment is an task of pricing policy. 
5. Target Marketing: Cheap goods are promoted to the market at low prices. Higher prices are fixed for luxury items. People are bothered of the prices of ordinary restaurants and hotels. But they are ready to pay more for luxury hotels, hotels inside airports and resorts.

6. Brand Positioning: The price of the product or service sends a message to consumers about the quality of the product. Cheap priced items may be perceived as cheap quality. Thus premium products are priced high, cheap products are priced low.

7. Increase in sales: If a firm wants a sudden increase in sales it may reduce it's price or offer discounts.

8. Maintain and increase market share: Pricing has an objective to maintain and increase market share.

\section{Factors Influencing Pricing-}

Factors influencing pricing:

(a) Internal Factors, (b) External Factors

\section{A. Internal Factors}

1. Marketing Objectives 3. Cost of transportation.

2. Cost of production 4. Cost of distribution. 
5. Cost of advertisement 7. Marketing Mix

6. Sales promotion strategy

\section{B. External Factors}

1. Demand of the product 4. Channels of distribution.

2. Competition

3. Government Policy
5. Entry and Exit barriers in industry

\section{Steps in formulating pricing}

Setting prices is an important element of marketing decisions. There are five steps in pricing decision: Setting price objective, estimation of demand, estimation of cost, analysis of competitor's price, selection of pricing method.

1. Setting price objective: The firm has to fix the main pricing objectives first. The objective can be survival, maximum current profit, maximum market share, maximum market skimming, product-quality leadership, etc.

2. Estimation of Demand: Forecasting the demand is another important element of price decision. Price influences the demand also. Surveys, price experiments and statistical analysis are done to estimate the demand for the product. 
3. Estimation of cost: Various costs such as fixed and variable costs should be estimated to fix the price of the product.

4. Analysis of competitor's price: The price set by the competitors, dealer margin and the quality of the product should be analysed before setting the price of the product.

5. Selection of pricing method: There are various pricing strategies such as Markup Pricing (20\% on cost), Target Return Pricing (based on ROI), Perceived-Value Pricing, Going Rate Pricing (charge what is prevailing in the market), Auction-Type (bid) Pricing, etc.

6. Selecting the Final Price: Final price is generally set on the basis of pricing methods. Companies will also consider additional factors such as impact of other marketing activities, riskreturn analysis, etc. while fixing the price.

\section{Pricing methods and strategies}

\section{(Pricing Policies/Approaches of Pricing)}

1. Cost Oriented Pricing Policy: This is the traditional method of pricing. Here a percentage of profit is added to the cost to fix the price. Price $=$ Total Cost + Fixed Profit \%. Eg. Busfare for public transport buses fixed by Kerala Govt .

2. Demand Oriented Pricing Policy: Here the focus is on the level of Demand. Cost of the 
product is ignored here. Dynamic Pricing is based on demand. Eg. Airline Pricing.

3. Competition Oriented Pricing Policy: Price is fixed on the basis of the price of competing firms. Going rate pricing, price skimming, price discounts, psychological pricing, etc. are competition oriented pricing. Eg. Price of FMCGs

4. Value (image) based pricing: When the price is fixed with an objective of creating an image of luxury or quality in the minds of market, value based pricing is used. Eg. Prices of medicinal shampoo, prices of Amway products, etc.

5. Relationship-Based Pricing: Here the pricing is based on the overall business of the customer with the company. This concept is originated in the banking industry.

6. Socially-oriented pricing: Here high prices are charged for harmful products such as tobacco, alcohol, etc. with an objective to reduce its consumption.

\section{Types of Pricing}

1. Premium Pricing. 7. Promotional Pricing.

2. Image/Prestige Pricing 8. Geographical Pricing.

3. Penetration Pricing. 9. Differential Pricing.

4. Economy Pricing. 10. Going-Rate Pricing.

5. Price Skimming. 11. Monopoly Pricing

6. Administered Pricing. 12. Odd Pricing 
1. Premium/Prestige Pricing: Shows the product is superior and unique. Eg. Parker pen.

2. Penetration Pricing: Low price initially to penetrate the market. When the market is established the company will increase the price. Eg. Jio Sim

3. Promotional Pricing: Here the firm reduces the price drastically for a short period of time to induce the market. Eg. Wood lands declares high discounts during specific seasons.

4. Economy Pricing: This sets a low cost approach. Moderate price is charged for the products. This method is popular during economic recession and depression.

5. Price skimming: Here high price is charged for the products in the initial stages. It aims to charge extra from those who are willing to pay. Eg. Iphones

6. Administered Pricing: Here the government regulates the price of the product. Market forces has no role in fixing the price. Eg. Bus fare, train fare, etc.

7. Geographical Pricing: Here separate price is fixed for different geographical areas. Eg. Price of petrol differs with the distance from the refinery. 
8. Differential Pricing: Here different prices are charged for different types of customers. Differential pricing is made on the basis of quantity, time of purchase, discount offers, etc. For eg. Vega land charges high rates on peak days and reduced rates for students.

9. Going-rate pricing: Here the prevailing price in the market is adopted by the company. 'Follow the leader' is a common practice there.

10. Monopoly Pricing: It is set by the monopolist firm. Generally monopolist fixes the price above the marginal cost.

11. Odd Pricing: It is a psychological method to appeal the buyers. For eg. Rs.99.99 gives a feeling of below hundred.

\section{Pricing of a new product}

Pricing a new product is a top management puzzle. There are a number of pricing strategies for new products. The study of market and competition has an important role in the pricing of new products. Companies will study the demand for the product and the price elasticity before making pricing decisions.

Price skimming and price penetration strategies are adopted by companies for the pricing of a new product. The high prices or low prices will either result in loss of customer or revenue. Hence initial 
pricing strategies are temporary. For a new product, estimation of demand, anticipation of the effect of various possible combinations of prices, etc. are necessary to choose the most suitable pricing policy.

Pricing a new product is the choice between Price skimming and Price Penetration:

\section{(1) Price Skimming:}

Policy of high initial prices that skim the cream of demand. Under this method high price is charged for the products in the initial stages. It aims to charge extra from those who are willing to pay. Eg. Iphones of Apple. A novel product, when it first came out, price skimming is adopted. It is because, the consumers remained ignorant about its value compared with the value of conventional alternatives. Since competition is also few, crosselasticity of demand will also be low.

\section{(2) Price Penetration:}

This policy is the reverse of the skimming policy. Under this method, Low price is initially charged to penetrate the market. When the market is established the company will increase the price. Eg. Jio Sim.

\section{Resale/Retail Price Maintenance (RPM)}

Retail Price Maintenance is an agreement between a manufacturer and a wholesaler or retailer not to sell a product below a specified price. If a reseller 
refuses to maintain prices, either openly or secretly, the manufacturer/dealer may stop doing business with it. There are two types of RPM. They are: minimum resale price maintenance and maximum resale price maintenance.

a) Minimum resale price maintenance: It is a contractual agreement where the distributors will sell the manufacturer's product at or above a price floor.

b) Maximum resale price maintenance: It is a contractual agreement where the distributors will sell the manufacturer's product at or below a price ceiling.

\section{Review Questions}

\section{Mark Questions}

1. What is odd price?

2. What is penetration pricing?

3. Explain the concept of 'price'

4. Define 'price'

5. What is 'price mix'?

6. What is price skimming?

7. What is demand oriented pricing policy

8. What is value based pricing?

9. What is retail price maintenance?

10. What are the four P's of marketing 
11. What is relationship based pricing?

12. What is 'dynamic pricing'?

13. What do you meant by penetration pricing?

14. What is differential pricing?

15. Give some examples for administered pricing.

\section{Mark Questions}

16. What are the elements of pricing decision?

17. What are the steps in fixing price?

18. What are pricing policies?

19. Explain RPM?

20. Explain the role of pricing in marketing strategy

21. 'Pricing helps in target marketing.' Comment?

22. Can you explain why 'odd pricing' is used by some brands?

23. How 'pricing' is useful for market penetration?

\section{Mark Questions}

24. What are the factors that influence pricing?

25 . What are the types of pricing?

26. Explain how you will fix the price for a new product. What are the common strategies for the pricing of new products?

27. 'A pricing strategy has to consider several factors for the success.' Substantiate the statement. 


\section{Module IV}

Physical Distribution Mix- - Logistic and Supply Chain Management - Elements- Channels of Distribution Types- Factors Affecting the Choice of a Channel of Distribution-Functions of various Intermediaries retailing- Types of retailing- Direct Marketing- Merits and demerits

\section{Components of distribution system:}

The distribution system involves two components: (a)

Channels of distribution and

(b) Physical distribution

Channels of distribution: - It means a process through which the products are transferred from the producers to the ultimate consumers. It also known as marketing channels. The channels members include agents of merchants, wholesalers, retailers and other middlemen in distribution. They perform all marketing functions.

\section{Physical Distribution}

Physical distribution includes all the activities associated with the supply of finished product at every step, from the production line to the consumers.

Physical Distribution Mix includes customer service, order processing, inventory control, transportation and logistics, and packaging and materials. 


\section{Logistics Management}

- The word logistics is derived from the Greek word 'Logistikos' and/or the Latin word 'Logisticus', both means "Science of Computing and calculating", or the French word 'Loger' means "art of Transport"

Logistics is the flow and storage of goods inside and outside the firm. LM includes "Planning, implementing and controlling the physical flow of goods, services and related information from the point of origin to the point of consumption."

$\mathbf{L M}$ is the Management of the flow of:

(a) Raw materials from the supplier to the producer (b) Finished goods from the producer to the customers.

\section{Types of Logistics}

\section{Supplier (Inbound) Logistics:}

Movement of goods and raw materials from supplier to the company.

2. Organisational (Outbound/Corporate) Logistics: Flow of goods from the company to the customer point.

3. Customer Logistics: How customers handles the product to his consumption point.

\section{Supply Chain Management (SCM)}

SCM is a set of approaches utilised to integrate suppliers, manufacturers, warehouses and stores, so that goods are produced and distributed in order to 
minimise the costs while satisfying the service level requirements.

\section{Objectives of Logistics Management}

1. Inventory Reduction- Order checking, Price, Payment and delivery

2. Reliable and Consistent Delivery PerformanceStorage of optimum quantity.

3. Freight Economy- Location, number, size, layout, ownership

4. Facilitates Outsourcing

5. Minimum Product Damages-Own /outsourced, modes

6. Quick Response- Speed, safety and cost of the movement of.

\section{Importance of Logistics Management}

1. Satisfaction of human wants.

2. Transmission of the benefits of large scale production to all.

3. Stability of demand, supply and price.

4. Major source of employment - (nearly $25 \%$ a/cs for distribution system).

5. Acts as an agent of change through interaction of people, culture.

6. Provides quality goods at reasonable rate.

7. Provides opportunities for development.

8. Helps to minimise the price. 


\section{Logistics Vs Supply chain Management}

\section{Logistics}

1. The flow/storage of goods inside and outside the firm.

2. Refers to activities within an organisation.

3. It is a portion of SCM.

4. The main aim is full customer satisfaction.

5. Only one organisation is involved.

6. An old concept.

\section{Supply chain Management}

1. The movement and integration of SCM.

2. Refers to networks of companies that work together.

3. SCM is a broader term.

4. Main aim is to gain a substantial competitive advantage.

5. More organisations are involved.

6. Comparatively new concept

\section{Channels of Distribution (Marketing Channels/Trade Channels)}

Marketing channels are sets of independent marketing institutions participating in the marketing activities.

Basic channels of Distribution/ Types of Channels Two Level Channel

Manufacturer $\longrightarrow$ Wholesaler $\longrightarrow$ Retailer $\rightarrow$ Customer

\section{One level channel}

Manufacturer $\rightarrow$ Wholesalor $\rightarrow$ Retailer $\rightarrow$ Customer

\section{Zero Level Channel}

Manufacturer

Detailer Customer 


\section{Functions of Channels of Distribution}

\section{(Role of Middlemen)}

1. Collection of Information: about potential and current customers, competitors, and other market players, demand, customer preference, etc.

2. Information flow-invoices, sales literature, specifications, receipts, orders, rules and regulations

3. Primary cash flow- Payment of products and suppliers.

4. Primary product flow- materials, components, suppliers, services, finished products.

5. Reverse product flow- Returns for repair, replacements, recycling.

6. Helps in Promotion: Promotional activities like advertising, sales promotion, etc.

7. Financing: Middlemen helps the manufacturer and customer in financing through bulk orders, advance and credit sales.

8. Risk Taking: Risk of loss is spread over all the channels.

9. Improving location and Time gaps: bridging of producer and consumer.

10. Provides customer education:

11. Provides/ helps in after sales service.

12. Helps in matching demand and supply.

13. Forecasting of demand. 
14. Breaking the bulk- Buying in bulk and selling in small quantities.

\section{Channel Design}

A firm can have any number of intermediaries in its channels. A "level zero" channel has no intermediaries at all, which is typical of direct marketing. A "level one" channel has a single intermediary, usually from the manufacturer to the retailer to the consumer.

\section{Factors Affecting the Choice of a Channel of}

\section{Distribution}

Channel distribution strategy is a method of controlling the flow of goods and services from the manufacturer to the end user. The following are the most important factors that affect the selection of a Distribution Channel System (DCS)
A. Distribution Intensity
B. Channel configuration.
C. Channel arrangement.

\section{A. Distribution Intensity}

\section{i.Intensive Distribution:- Aims at maximum} possible coverage (availability) of his products. Products are distributed through every reasonable outlet in a market.

Eg. (FMCGs like Pen, pencil, sweets, toilet soaps, tooth paste, etc.

ii.Selective Distribution:- Limits the availability of the product to a limited number of outlets. 
Eg. Branded products like 'Louis Philippe', 'Van Heusen', 'Raymond's, etc.

iii.Exclusive Distribution:- Very few Distributors are appointed in a specific geographical area.

Eg. Vehicle manufacturers.

\section{B. Channel configuration.}

Configuration is an arrangement of functional units according to their nature, number, and chief characteristics. It is the design, composition and size of a distribution channel. Eg. Arranging wholesalers, agents, distributers, retailers, etc.

\section{Channel arrangement.}

Distribution channel is made up of various intermediaries. Channel arrangement is the level of relationship- mutual trust and understanding between them. The following are the types of channel arrangement:

(i) Independent channel: Conventional form. Channel members are not concerned about the chain as a whole. Each member functions independently. Eg. LIC agents

(ii) Dependent channel (Vertical Marketing System-VMS): Channel members are united and working together towards similar goal. Members maintain close contacts. Eg. Reps of dealers of passenger cars.

(iii) Horizontal Marketing System- HMS: Channel members on the same level cooperate. (say two 
suppliers/two Retailers). Eg. News paper distribution, mobile tower sharing.

Factors affecting Choice of channel of Distribution

1. Market Factors -

(a) Number of buyers, (b) Geography,

(c) order size,

(d) nature of buyer.

2. Product Factors-
(a) Perishability
(b) Unit value
(c) Weight
(d) New products

3. Company Factors

(a) Financial resources (b) Size of the company

(c) Distribution policy

\section{Middlemen Factors}

(a) Availability of middlemen

(b) Attitude of middle men

(c) Services

(d) Sales potential

\section{Environmental Factors}
(a) Social
(b) Economic
(c) Political

\section{Market Factors -}

(a) Number of buyers:

Large number of buyers- Long channel.

Eg. FMCGs

Limited number of buyers- Short channel

Eg. Passenger cars

(b) Geography: 
Highly scattered buyers- Long channel

Eg. Special Medicines like cancer.

Organised group of buyers- Short channel

Eg. HIV medicines

(c) Order size:

Bulk Orders - Short Channel/ Direct Selling

Eg. Medicines to Medical Colleges, etc.

Small Quantity orders - Long channel. Eg FMCGs

(d) Nature of buyer:

If the buyer wants direct dealing, zero level channels is possible.

\section{Product Factors-}

(a) Perishability :-

Highly perishable - Short channel

Eg. Fish, Meat, milk, vegetable

(b) Unit value

Low unit value -Possibility of middlemen.

Eg. FMCGs

expensive goods- Short channel

Eg. Passenger cars

(c) Weight

Heavy Weight- Short channel

Eg. Printing Press

Light goods - possibility of middlemen

Eg. FMCGs

(d) New products/ low demand - Short channel. 


\section{Company Factors}

(a) Financial resources:

Financially Weak - Financially strong intermediaries.

Financially Strong - Reduced Intermediaries.

(b) Size of the company:

Wide Range of products and Market share -Less Intermediaries

(c) Distribution policy:

Policies on speed of delivery, safety and efficiency.

\section{Middlemen Factors:}

Availability, efficiency and cost of middlemen involved in the process.

(a) Attitude of middlemen: Generally they select a product with higher returns and brands. So for a new firm short chain is practical.

(b) Availability of middle men: If the right type of middlemen is not available, zero level or a short chain is possible.

(c) Services: Availability of middlemen who are able to provide essential services like warehousing, promotion and after sale service.

(d) Sales potential: Availability of middleman with high sales potential.

\section{Environmental Factors:}

Choice of channel is affected by the prevailing business environment. 
(a) Social - Customer literacy, use of technology

(b) Economic - Economic cycles

(c) Political- Tax systems

\section{Channel Conflict / Disintermediation}

Competition between members in the same channels of distribution is called channel conflict. It happens when the members break the mutually agreed channel route. Conflicts occur when a channel sells products at lower prices.

Eg. Direct selling by manufacturer, retail sale by wholesaler, etc.

\section{Types of channel conflict}

1. Vertical Channel Conflict: Conflict between higher and lower levels. Eg. Manufacturer and wholesaler, Wholesaler and retailer, etc.

2. Horizontal Channel Conflict: Conflict between same levels of a channel. Eg. between wholesalers, retailers, etc.

3. Multi-Channel Conflict: Conflict between two or more channels of distribution.

\section{Conflict Resolution strategies}

1. Communication.

2. Formation of dealer councils.

3. Prioritising customer satisfaction.

4. Arbitration and Mediation.

5. Transparency in dealings. 


\section{Retailing}

Retail is the process of selling consumer goods or services to customers through multiple channels of distribution to earn a profit. Retailers satisfy demand identified through a supply chain. Retailing involves buying product or a service from a manufacturer, wholesaler, agent, importer or other retailer and selling it to consumers for their personal use. The price charged for the goods or services covers the retailer's expenses and a profit.

\section{Types of retailing}

Types of Retail outlets includes departmental stores, Discount Stores, supermarket, Warehouse Stores, Speciality Stores, malls, E-Tailers, Dollar Stores, Convenience stores and drug stores

\section{Department Stores}

A department store is a set-up which offers wide range of products to the end-users under one roof. Here, the consumers can get almost all the products they aspire to shop. They provide a wide range of options to the consumers to fulfill all their shopping needs.

Merchandise: Electronic Appliances, Apparels, Jewellery, Toiletries, Cosmetics, Footwear, Sportswear, Toys, Books, CDs, DVDs

Examples - Shoppers Stop, Pantaloon

\section{Discount Stores}

Discount stores offer products to the end-users at a discounted rate. The discount stores generally offer a 
limited range. Te quality in certain cases might be a little inferior as compared to the department stores.

Wal-Mart currently operates more than 1300 discount stores in United States. In India Vishal Mega Mart comes under discount store.

Merchandise:

Almost same as department store but at a cheaper price.

\section{Supermarket}

A retail store which generally sells food products and household items, properly placed and arranged in specific departments is called a supermarket. A supermarket is an advanced form of the small grocery stores. It caters to the household needs of the consumer. The various food products (meat, vegetables, dairy products, juices etc.) are properly displayed at their respective departments to catch the attention of the customers. Customers can pick any merchandise depending by themselves.

Merchandise:

Bakery products, Cereals, Meat Products, Fish products, Breads, Medicines, Vegetables, Fruits, Soft drinks, Frozen Food, Canned Juices

\section{Warehouse Stores}

Warehouse store is a retail format which sells limited stock in bulk at a discounted rate. Warehouse stores do not bother much about the interiors of the store. The products are not properly displayed. 


\section{Specialty Stores}

As the name suggests, Speciality store would specialize in a particular product and would not sell anything else apart from the specific range. Speciality stores sell only selective items of one particular brand to the consumers and primarily focus on high customer satisfaction.

Example-Book stalls, Medical stores.

You will find only Reebok merchandise at Reebok store and nothing else, thus making it a speciality store. You can never find Adidas shoes at a Reebok outlet.

\section{Malls}

Many retail stores operating at one place form a mall. A mall would consist of several retail outlets each selling their own merchandise but at a common platform. Recreational facilities are also there including food stalls and cinema halls.

\section{E Tailers (E-commerce Stores)}

Now a day the customers have the option of shopping while sitting at their homes. They can place their order through internet, pay with the help of debit or credit cards and the products are delivered at their homes only. This kind of shopping is convenient for those who have a hectic schedule and are reluctant to go to retail outlets.

Example - EBAY, Rediff Shopping, Amazon, Flipkart 


\section{Dollar (China) Stores}

Dollar stores offer selected products at extremely low rates but here the prices are fixed.

Example - 99 Store would offer all its merchandise at Rs 99 only. No further bargaining is entertained. However the quality of the product is always in doubt at the discount stores.

9. Mom and Pop Store (Kirana Store- in India)

Mom and Pop stores are the small stores run by individuals in the nearby locality to cater to daily needs of the consumers staying in the vicinity. They offer selected items and are not at all organized. The size of the store would not be very big and depends on the land available to the owner. They wouldn't offer high-end products.

Merchandise: Eggs, Bread, Stationery, Toys, Cigarettes, Cereals, Pulses, Medicines

\section{Chain stores:}

Chain stores are similar shops owned by same person at different locations. They deal in similar products.

\section{Drug stores}

Drug stores are those which sell medicines. They are specialized in medicines. Now a day they sell many other things besides pharmaceuticals. They sell health and beauty products, basic snacks, protein supplements, small medical equipment as well as other personal care and healthcare products, etc. 


\section{Convenience stores}

A store in the locality which provides the most basic material to the local customers are called convenient store. These are small stores which do not have too much depth in their product line. They will have 2-3 types of each product. Nonetheless, they are almost anywhere.

\section{Consumer cooperative stores:}

Consumer cooperative store is a retail unit owned and controlled by consumers. Any consumer can join the consumer cooperative store by buying its shares. It functions under Cooperative Societies Act. They cater mainly the needs of their members.

\section{Franchise:}

A franchisor licenses its know-how, procedures, intellectual property, its business model, brand, etc. to a franchisee. Franshisee uses the brand to offer similar product and services.

For eg. Computer courses of C-Dit (Centre for Development of Imaging Technology) of Kerala Govt. and C-Dac (Centre for Development of Advanced Computing) of Govt. of India.

\section{Direct Marketing}

Movement of goods from the producer to consumer directly without a middleman is called DM. It includes: (a) Direct Selling and (b) Direct Response selling. 
(a) Direct Selling:- Door to Door selling or face to face selling.

(b) Direct Response Selling:-

- Mail, Email, Catalogue, sms,

- TV, telemarketing, radio, telephone/mobile phone.

- E Commerce, Web marketing,

- I marketing, Social media marketing.

- Kiosk marketing- customer order placing machine.

\section{Direct Marketing}

1. Direct Communication with Customer.

2. Mostly personal

Communication

3. Tailor maid product offers to individuals.

4. Company has full control over the delivery of product.

5. Tries to maintain personal relationship with each customer.

\section{Marketing}

1. Mass Communication.

2. Impersonal

Communication.

3. Uniform product offers to all customers.

4. Company has limited control over distribution network.

5. Personal relationship with all customers is not possible. 


\section{Direct Marketing- Merits and demerits}

\section{Merits}

1. Find new customers: Direct marketing helps you build a list of new potential customers.

2. Target most likely customers: Direct marketing helps to create lists and to reach potential customers.

3. Communicate with existing customers for repeat business or upsell. It helps to stay in touch with customers with direct marketing to promote a special offer, promotion or event and let them know about other services.

4. Quick production and turnaround. Commercial printers offer fast turnaround time to get direct mail out to customers. An email can also be created very quickly and sent out to customers.

5. Advertise specific products, services, special offers and events. With direct marketing, you control the message and offer.

6. Branding your business can seem like an expensive notion, but by simply creating a cohesive direct marketing campaign, you can create a recognizable company brand.

7. Personalize for a better response. Addressing the recipients by name and even printing messages offers better ways for businesses and organizations to connect with customers.

8. Track and measure results. Direct marketing offers ways to track and measure your results, so you know just how many customers you've 
reached, the response you've received, and how much money you spent per customer.

9. It's cost effective. When you break it down by ROI, direct marketing is a cost effective marketing solution.

10. Campaigns are easy. With direct marketing you can choose between postcards, letters, catalogues, trans promo marketing (marketing on billing statements), email marketing and more.

\section{Demerits}

1. Expensive

2. Time Consuming

3. Limited Coverage

4. Inconvenient or obstructive for business clients or consumers

5. Channel Saturation: Consumers are less inclined to give attention to those messages. For example, consumers regularly throw away direct mail pieces and delete marketing emails without even opening them.

6. Perception Problems: Businesses employing direct sales marketing techniques may also face a perception problem, particularly among first-time, direct sales customers. For eg customers that do not normally buy from direct sales businesses tend to have a slightly negative perception of both direct sales and direct sellers. 


\section{Review Questions}

\section{Mark Questions}

1. Who is a wholesaler 2010, 2012,

2. Define 'channel of distribution' 2011,

3. What is meant by physical distribution mix?

4. What is logistics management?

5. What is customer logistics?

6. What is meant by inbound logistics?

7. What is Zero level channel? Why it is called so?

8. What is meant by intensive distribution?

9. What is 'channel configuration'?

10. What is 'channel arrangement'?

11. Explain VMS.

12. Explain HMS.

13. What is channel conflict?

14. What is retailing?

\section{Mark Questions}

15. What is logistic management? Describe different types of logistics? 2013,

16. State some of the advantages of having a proper logistic system. 2014,

17. What are the components of distribution system?

18. What are the types of logistics?

19. Specify the special objectives of 'logistics management'

20. Differentiate logistics and SCM

21. What are various forms of 'trade channels'?

22. What are the types of 'channel arrangement'?

23. Differentiate Marketing and Direct marketing. 


\section{Mark Questions}

24. Discuss the factors which influence the selection of channels of distribution

25. Define marketing channel. What are the factors to be considered while choosing a channel of distribution?

26. Explain the role of middlemen in marketing.

27. What are the factors affecting the choice of a distribution channel?

28. "Competition between members may result into channel disintermediation". Substantiate and suggest strategies for conflict resolution.

29. Explain the types of 'Retailing'

30. What is direct marketing? Explain the pros and cons of direct marketing 


\section{Module V}

Recent Trends in Marketing (Overview Only)Relationship Marketing - Social Marketing -Online Marketing- -Green Marketing-Tele Marketing -Viral Marketing- Relationship Marketing-De-marketingRemarketing- Guerilla marketing - Ambush Marketing. (6 Hours)

Market - derived from the Latin term means "To trade" The term 'Market' denotes a place, assembly of buyers and sellers, area of operation, organization for exchange of commodities, act of buying and selling, exchange orientation, market firms, etc.

\section{History of Marketing (Philip Kotler)}

1. The production era: (before 1925).

The focus was on production. Consumers will favor those products that are widely available and low in cost. Firms concentrate on achieving high production efficiency and wide distribution.

\section{The product era:}

Consumers will favor those products that offer the most quality, performance or innovative features. Marketing managers focus on making superior products and improving them over time.

\section{The sales era:}

(1920 to 1950). Focus on sales promotion. Efforts were for aggressive selling and promotion effort. 
Selling is focused on the seller's need to convert his product into cash.

4. The marketing era: (1945 to 1980)

Focus on marketing of goods and services and on the needs and wants of customers. "Selling focuses on the needs of the seller, marketing on the needs of the buyer." Marketing is pre occupied with the idea of satisfying the needs of the customer.

\section{The relationship era: (1990 onwards)}

Here the focus is on customer building. Relationships with customers, suppliers, employers, supplies chains, etc. are given importance.

Production, product, selling, marketing and holistic marketing are 5 competing concepts. Out of this production, product and selling have limited use now a day.

\section{The modern marketing concept (Holistic marketing concept)}

HMC is based on development, design and implementation of marketing programs, considering all the stake holders such as Customers, Employees, Marketing partners (Channels, suppliers, dealers, etc.), Members of the financial community (stock holders, investors, analysts, etc), Govt., Society, etc. It considers all the elements in the production and distribution process. Holistic marketing concept leads to relationship marketing. 


\section{Relationship marketing (RM)}

RM is based on satisfying the customer needs and build lasting relationships. Under this concept 'current customers are the key to long term business successes. Customer relations are very basic to business. Long term relationship building goal is importance because:

(a)Acquiring new customers can be five times more expensive than the cost of retaining existing customers

(b) An average company losses $10 \%$ of it's customer every year.

\section{Elements of Relationship marketing}

1. Welfare of customers. It tries to give over and above the customer expectations.

2. Trust in honesty (promises and obligations) and benevolence (kindness) is the interest in the welfare of others.

3. Commitment is the continuous desire to maintain good relations.

4. Service is the result of trust and commitment.

5. The levels of relationship may start from discount offers to social interactions and interdependence.

\section{Elements of Modern Marketing:}

1. Customer orientation

2. Radical transparency and real time picture.

3. Quality.

4. After sale service.

5. Competitor orientation. 
6. Change in the concept of profit orientation.

7. Marketing in a digital world and inclusion of people with heavy digital DNA in the marketing team.

8. Agility (quick) marketing to tap elusive (indefinable) consumer with short-term thinking.

9. Shift from globalization to personalization.

10. Change in the concept of 'product'

\section{The modern concept of 'Product'}

(Scope of Modern Marketing)

1) Goods and Services.

2) Event Management.

3) Experience marketing - Theme parks, film city

4) Place Marketing - tourist places KTDC, GTDC, DTDC

5) Self/Individual Marketing - celebrities.

6) Marketing of rights, real estate and financial properties

7) Educational Institutions.

8) Information marketing - Research articles, journals.

9) Personal information - Social Medias, search engines, free applications, etc.

10) Idea/Awareness Marketing - save water, save electricity, save nature.

11) Consultancy (Kotler, CK Prahlad, etc.).

12) Charitable Service Marketing - Naik foundation. 
13) Technology, Web hosting, Web designing.

14) Cyber Space.

15) Cyber Security - Visa/Master, Bill desk, Razorpay

\section{Emerging Trends in Marketing}

1. Direct Marketing- Direct selling, Direct Response Selling

2. Relationship Marketing- CRM \& PRM

3. E-Marketing (E Commerce)

4. Tele-Marketing (Inside Sales): - Automated, Inbound, Outbound

5. Viral Marketing (Word of Mouth Marketing)

6. Social Marketing

7. Social Media Marketing (SMM)

8. De marketing (Un selling/ Marketing in Reverse) - General, Selective, Ostensible

9. Re marketing

10. Synchro Marketing

11. Service Marketing

12. Event Marketing

13. Counter Marketing

14. Green/Eco(Environmental) Marketing

15. Speed (Turbo) Marketing

16. Micro Marketing

17. Niche Marketing

18. Individual Marketing

19. Personalised (One 2 One) Marketing 
20. Business 2 Business Marketing

21. Business2 Consumer Marketing

\section{Direct Marketing.}

Movement of goods from the producer to consumer directly without middlemen is called DM. It includes:

(a) Direct Selling and (b) Direct Response selling.

(a) Direct Selling:- Door to Door selling or face to face selling.

\section{(b) Direct Response Selling:-}

Here the company initiates selling efforts only to those customers who respond to advertisements. The following are the channels used for inducing response (Direct response selling):

- Mail, Email, Catalogue, sms, etc.

- TV, radio, telemarketing, telephone/mobile phone.

- E Commerce, Web marketing, I marketing, Social media marketing.

- Kiosk marketing- customer order placing machine.

\section{E- MARKETING ( E Commerce) :}

Application of internet, mobile phone and related technologies in marketing is called e-marketing. It includes creation, display, promotion, order, payment and distribution of products. It uses internet, website, email, mobile phones, net banking/credit cards, etc. Types of E- MARKETING includes: 
1. Banner Advertisement: Ads on other webs.

2. E-mail Marketing: Emails to prospective customers.

3. Partnership/Affiliate Marketing: Selling other firms products through firm's websites. Eg. Flipcart, Amazone

4. Search Engine Marketing (SEM) : Listing the products of company with search engines like Google, Yahoo, MSN, etc.

\section{Telemarketing (Inside sales)}

Prospective customers are contacted over phone to induce purchase of products of the company. These calls are known as cold calls, since they are made not as per the request of the customer. Call centre is the hub or central point of a tele-marketing company.

\section{Types of Telemarketing}

a) Automated Telemarketing: Uses pre-recorded message while calling. IVR (Interactive Voice Response) technology permits interactions to a limited extent. Eg. BSNL service centre.

b) Inbound Telemarketing: Responses of company to incoming calls from the customers. Incoming calls may be the result of advts, publicity, efforts of sales people, tele-brand shows, etc

c) Outbound Telemarketing: Contacting prospective customers directly over phone to purchase the products of the company. 


\section{Viral (Word of Mouth) Marketing (viral advertising, or marketing buzz):}

They are buzzwords referring to marketing techniques that use pre-existing social networking services. Word-of-mouth marketing is a strategy that encourages individuals to pass on the marketing message to others. Word of mouth messages can be positive, neutral or negative. Here product information is transmitted from consumer to consumer. It is a marketing technique whereby information about a product or services is passed electronically from one Internet user to another. Generally viral marketing uses social networks like FaceBook, WhatsApp, Twitter, etc .

\section{Social Marketing (S. Responsibility Marketing): ie Customer wants + Public interest + Profit} Use of marketing principles and techniques to promote a social cause, idea or behavior is called SM. The objective is to change the behavior for improving health, protecting environment, preventing injuries, etc. Objectives of SM includes:

(a) Improve the welfare of consumers.

(b) Protection of environment.

(c) Consumer education.

(d) Increase the image of the company.

Eg. Campaigning against cigarette smoking, alcohol consumption, etc.

Campaigning for obeying traffic rules, save water, save fuel, environment protection, etc. 


\section{Synchro Marketing:}

The process of adjusting and balancing demand and supply with seasonal fluctuations is called synchro marketing. It attempts to balance out seasonal and cyclical fluctuations in demand. For eg. A cotton shop is crowded during summer season whereas during winter it is not. School bags, uniforms, socks and shoes, umbrellas, etc. are other common examples. Off season discounts, differential pricing, etc are strategies of synchro marketing.

\section{Service Marketing:}

Services are referred to as economic services offered by one party to another. A service is intangible and perishable in nature. There is no transfer of ownership, but one can feel it.

Eg. Banking, Hospital, Hospitality, financial services, consultancy, insurance, etc.

\section{Service Marketing Mix (7 P's):}

Product, Price, Place, Promotion, People, Process, Physical environment/evidence.

Marketing Mix in Service Marketing includes Product Mix (luxury/Economy rooms of hotels), Price Mix (lower rates in off season and high rates in season), Place mix (On road service, airport/railway station picking) and Promotion mix (Direct mail, personal selling, etc).

\section{Event Marketing:}

Event-marketing is concerned with exploiting the happening of an event in every walk of social life. 
Entertainment and the sports are the most common areas where event marketing is fully exploited. Sponsorship, patronage public-relations and vehicles of advertising are used for event marketing.

Eg. Sahara India Pariwar-

Sponsor of the Bangladesh Cricket Team.

(Indian conglomerate with HQ in Lucknow)

9. Green (Eco)-Marketing (Environmental Marketing and Ecological Marketing)

According to the American Marketing Association, green marketing is the marketing of products that are presumed to be environmentally safe. Thus green marketing incorporates a broad range of activities, including product modification, changes to the production process, change in packaging, as well as modifying advertisement, etc. Eco-friendly products are "products that do not harm the environment whether in their production, use or disposal".

Eg. IRCTC's (Indian Railway) e-ticket, Wipro and Infosys's are going green Wipro launched desktops, laptops are known as Wipro green wares.

Nimse (2007) defined green products as those that use recyclable materials, minimal wastage, and reduce the use of water, save energy, have minimal packaging, and emit less toxic substances. Compared with other products, green products bring less harm to humankind. Green products are environmentally friendly products. Eg. Paper bags, e-bills, e-tickets, etc. 


\section{Speed (Turbo)-Marketing}

A company can try to make marketing advantage in four ways; make a better offer, a newer offer, a cheaper offer or a faster offer. Making a faster offer to take marketing advantage is called Turbo marketing. Turbo marketing is applied in four areas: innovation, manufacturing, logistics and retailing. Speeding up innovation is essential in the age of shorter product life cycle.

Eg. 4g net by Airtel, speed post by Post office, home delivery by retailers, e-commerce outlets by retailers, mobile applications, etc.

\section{Counter-Marketing}

Counter marketing is a deliberate attempt to damage or totally kill the demand for the goods and services. Those goods are known for harmful effects on the consumers. Eg. Alcohol consumption, occasional smoking, unsafe sex, use of powerful pesticides, fertilizers, and drugs.

\section{De Marketing (un selling / marketing in reverse)}

De marketing is an attempt to reduce or limit the demand for consumption of a product. When a company discourage its customers to buy their product, it is called de-marketing. It is done when there is excess demand for the product.

Kotler and Levy define demarketing as "discouraging customers in general or a certain class of customers in particular on either a temporary or a permanent basis". 
Eg. Water/Electricity/Fuel conservation, paper/plastic reduction, Cigarette smoking, etc.

a) General Demarketing:

Objective is to reduce total demand for the product. Eg. KSB, Petroleum, etc

b) Selective Demarketing:

Objective is to discourage demand from certain class of customers or during peak hours.

Eg. Tobacco products to under the age of 18 , restrict the use of electricity during $6 \mathrm{pm}$ to $8 \mathrm{pm}$.

c) Ostensible Demarketing:

Firm creates artificial scarcity of products to increase demand.

Example:

- BMW announced in 1997 that it was to restrict supply to the UK market. It was ostensible because the sales kept rising from 60,000 cars to 180,000 in 2012. It was strategic because it was a decision made and announced by BMW itself. It was demarketing because the threat of restricting supply seems to have been made to boost sales.

\section{Re Marketing:}

Re-marketing means renewed use of a product in which market has declined. It involves reintroduction of a product or service as a result of steep fall in demand. Price, place and promotion mix are also modified to increase the demand.

Eg. BSNL Land line. 


\section{Micro marketing}

Micro marketing is a marketing strategy in which promotional strategies are focused on a small group of consumers. Advertising efforts are focused on this micro group of targeted consumers. There are marketing strategies focused on Govt Employees, rich men, college students, etc.

Eg. Couple's plan, students plan, etc. of BSNL

\section{Niche marketing}

Niche market is a subset of the market. Here the focus on a specific product. A niche market must satisfy specific market needs like Price Range, Production Quality, demography, etc.

Eg. JCB, Jeep, BMW car, etc. are niche product, because only a small segment of the market needs it.

\section{Individual marketing}

Individual marketing means tailoring products and marketing programs to the needs and preferences of individual customers. Here, products are customized to suit each person.

The demand is directly communicated to the suppliers or manufacturers and they can be provided with customized products as per their demand.

Eg. Vehicles for handicapped, holyday packages, etc.

\section{Personalised (one-to-one) marketing}

A marketing strategy by which companies uses data analysis and digital technology to deliver 
individualized messages and product offerings to current or prospective customers.

Eg. Amazon offers individual product suggestions based on preferences, search history and previous purchases.

\section{Cyber (Online/Internet) Marketing}

It simply refers to a technique of attracting potential customers by advertising your products or services through such means as websites, emails, and banners.

\section{Types of Online marketing}

a) Search Engine Marketing: includes Search

\section{Google}

HP laptop

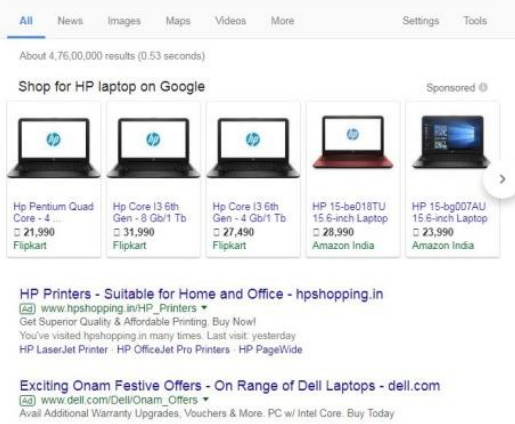

Engine Optimization (SEO) and Search Engine Marketing (SEM).

a. SEO is the process of tuning your business website so that it ranks higher in the search listings. when potential customers enter search terms that match your product offerings. SEO is free.

b. SEM is paid search marketing - Search engines (eg. Google) will display your ad when a user enters a search using one of your keywords. It gives excellent feedback on the effectiveness of the ad. 
(the number of clicks on the ad versus the number of times the page has been viewed).

b) Online Advertising - Besides banner ads and SM on the internet, different social media, such as Facebook, offer their own advertising platforms. They are called online advertising.

c) Email Marketing - Here the market creates email list of potential customers and sends email advertisements. Email marketing is a very effective way to get the message out. Customers are updated with company news, upcoming events, and special offerings.

d) Mobile marketing - SMS and mobile applications are the best way to reach potential customers.

e) Blogging - having a business blog is a way to talk with customers and keep them informed about your products or services. A blog can be used to provide advice and get useful feedback.

f) Social Media Marketing - social media platforms such as Twitter, Facebook, LinkedIn, WhatsApp, etc. give opportunities for marketing online. Social media is a conversation. It requires active participation rather than just posting ads.

\section{Mega Marketing:}

It is a marketing activity to manage the elements of firm's external environment. These environments include third parties that influence the transactions. For eg. govt., media, labor union, regulatory organisations, other pressure groups, etc. 


\section{Meta Marketing:}

There are two ideologies with meta marketing.

(a) Meta marketing is an attempt to widen the horizons of marketing by non-profit organisations.

Eg. Selling family planning ideas.

(b) Meta marketing also means bringing together closely related products under one umbrella. Generally it happens with web based marketing. Eg. When we search for mobile phone in Amazone/Flipcart, they will also show the links of cover, power bank, etc.

\section{Differential Marketing:}

Here two or more market segments are targeted with different products.

Eg. A retailer may offer quality (top rated), Medium range, Economy and cheap shoes at the same shop. Titan offers differentiated brands to cater different sectors of the economy-Nebula to Sonata.

\section{Concentrated Marketing:}

Concentrated Marketing is a strategy whereby a single segment is concentrated with a single brand/product. It may help to become very successful in a particular segment.

Eg. Rolex Watch, Rolls-Royce Motor Cars, etc. concentrates on luxury segment only.

\section{Guerrilla Marketing}

It is an advertising strategy that uses unconventional marketing tactics and surprise that yield maximum results. Guerrilla marketing is relatively inexpensive. 
But it needs imagination. Even foot path writing may get the attention of passengers. Guerrilla marketing is all about smart ideas of cheap advertising to capture the attention in an effective manner. Examples include the use of publicity stunts, viral videos (eg. Kochin colleg's Jimicky kammal), flash mobs, etc.

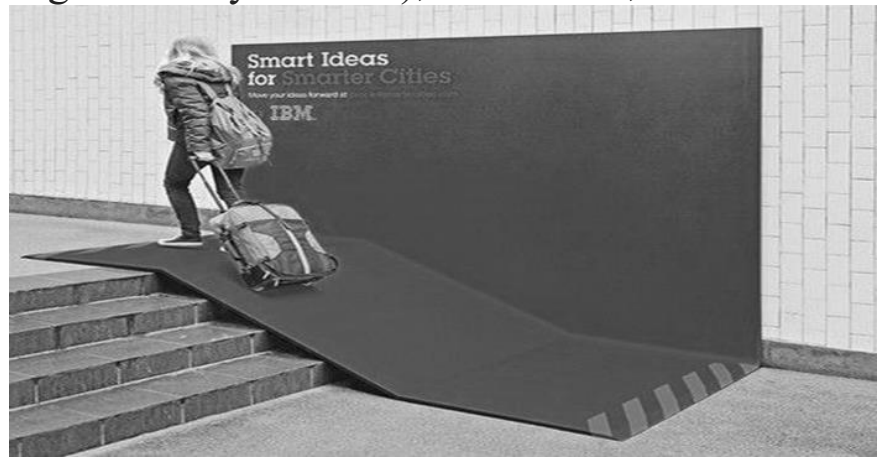

\section{Ambush Marketing:}

Ambush marketing is a marketing technique in which a firm takes an advantage of a famous event. It is called ambush marketing, because, the firm does not pay for it. For instance a firm pretends to be the sponsor of world cup. Actually he is not a sponsor. This marketing some times, considered as illegal, because it is against the exclusive rights of actual sponsor.

For eg. A football tournament is exclusively sponsored by the company 'Adidas'. 'Nike' offer free logo printed tea shirts to 500 audiences; it can be considered as ambush marketing by 'Nike' 


\section{Review Questions}

\section{Mark Questions}

1. What is demarketing 2010, 2012,

2. What is Tele-Marketing 2010,

3. What is viral marketing 2011,

4. What is remarketing 2014,

5. State the scope of E-Marketing 2010,

6. State any three characteristics of E-Markets . 2011, 2012

7. What is synchro marketing 2011,

8. How does E-Marketing works 2013,

9. Explain any two characteristics of service 2014,

10. What is HMC?

11. What is RM?

12. Briefly explain direct response selling.

13. What is E Commerce?

14. What is meant by SEM?

15. Explain inside sales.

16. What is marketing buzz?

17. Give few examples of service marketing.

18. What is event marketing?

19. What is your concept of Turbo marketing?

20. What is marketing in reverse?

21 . What types of marketing that discourages the customers from using their products?

22. What is mega marketing?

23. Briefly explain meta marketing.

24. Guerrilla marketing

\section{Mark Questions}

25. Explain the main components of modern concept of marketing 2011, 
26. What are the advantages of tele-marketing 2014,

27. What are the elements of modern marketing?

28. Explain the types of direct marketing.

29. What are the types of E marketing?

30. What is telemarketing? What are its various forms?

31. How 'social marketing' does help the society?

32. How 'green marketing' is beneficial to the environment?

33. How 'counter marketing' is beneficial to the society?

34. Why ostensible DE marketing is considered unethical?

35. Differentiate Remarketing and De marketing.

36. Differentiate micro marketing and Niche marketing.

37. Differentiate individual marketing and Personalised marketing.

38. Differentiate 'differential marketing and concentrated marketing'

\section{Mark Questions}

39. Present a comparative study between the traditional and modern concept of marketing 2014,

40. Discuss the functions and importance of modern marketing 2015,

41. "The modern concept of 'product' gives vast opportunities for marketing". Substantiate the statement with changes in the concept of 'product'

42. Explain the scope of modern marketing

43. "Cyber marketing is the order of the day." Explain the various types of cyber marketing. 


\section{INDEX}

Administered Pricing, 52, 61

Ambush Marketing, 103

Economy Pricing, 61

Event Marketing, 95

4 Cs theories, 9

4 P's of marketing, 9

7 Ps of Marketing, 9

Bases Market Segmentation, 17

Basic channels Distribution, 69

Behavioural Variables, 21

Blogging, 101

Brand Associations, 45

Brand awareness, 44

Brand Equity, 44

Brand image, 45

Brand Loyalty, 45

Brand Positioning, 57

Branding, 41

Broad environment, 7

Business analysis, 35

Chain stores, 80

Channel arrangement, 72

Channel configuration, 72

Channel Conflict, 76

Channel Design, 71

Channels Distribution,66,69,73

China Stores, 80

Combination Branding, 43

Competition Oriented Pricing,60

Concentrated Marketing, 28, 102

Concept Testing, 35

Conflict Resolution strategies, 76

Consumer cooperative stores, 81

Consumer Products, 31

Convenience stores, 81

Corporate Branding, 43

Cost Oriented Pricing, 59
Counter-Marketing, 97

Customer Logistics, 67

Corporate Logistics, 67

De Marketing, 97

Demand Oriented Pricing, 59

Demographic variables, 17

Department Stores, 77

Dependent channel, 72

Differential Marketing, 102

Differential Pricing, 52, 62

Differentiated Marketing, 25

Dimensions of Product Mix, 32

Direct Marketing, 81, 84, 92

Direct Response Selling, 92

Direct Selling, 92

Discount Stores, 77

Disintermediation, 76

Distribution Intensity, 71

Distribution system, 66

Dollar Stores, 80

Drug stores, 80

Eco-Marketing, 96

E Commerce, 92

E- marketing, 92

E Tailers, 79

E-commerce Stores, 79

Economy Pricing, 51

Elements Modern Marketing, 89

Elements of Positioning, 24

Elements Pricing Decisions, 55

Email Marketing, 101

Essentials of good packaging,47

Factors of Pricing, 49, 57

Failure of new products, 36

Family Branding, 42

Features of Product, 30

Franchise, 81 
Functions of marketing, 7

General Demarketing, 98

Geographic Variables, 20

Geographical Pricing, 52

Going-rate pricing, 62

Going-Rate Pricing, 52

Green Marketing, 96

Green products, 96

Guerrilla Marketing, 102

History of Marketing, 87

HMC, 88

Holistic marketing concept, 88

HMS, 72

Idea Generation, 34

Idea Screening, 34

Image Pricing, 51

Logistics Management, 68

Image based pricing, 60

Inbound Logistics, 67

Independent channel, 72

Individual Branding, 43

Individual marketing,28, 99

Industrial Products, 31

information utility, 3

Inside sales, 93

Intensive Distribution, 71

Kirana Store, 80

Logistics Management, 67.68

Logistics Vs SCM, 69

Malls, 79

Market, 87

Market, 1

Market Positioning, 23

Market Positioning Strategies, 24

Market Segmentation, 14,27

Market Targetting, 21

Market Vs Marketing, 2

Marketing and selling, 3

Marketing, 1 marketing buzz, 94

Marketing Channels, 69

Marketing Concept, 5, 6

Marketing environment, 6

marketing era, 88

marketing in reverse, 97

Marketing Management, 4

Marketing Mix, 9, 12,13

Mkting Mix-Service Mkting,95

Marketing of services, 48

Mass Marketing , 27

Mega Marketing, 101

Merits of Direct Marketing, 83

Meta Marketing, 102

Micro marketing, 99

Micro Marketing, 14

Misguided enthusiasm, 37

Mobile marketing, 101

Modern concept of 'Product', 90

Modern marketing concept, 88

Mom and Pop Store, 80

Monopoly Pricing, 52, 62

Need of segmentation, 16

Need -Product Development,33

New Product Development, 34

Niche marketing, 99

Objectives of Pricing, 49

Odd Pricing, 52, 62

One-to-one marketing, 99

Organisational Logistics, 67

Ostensible Demarketing, 98

Outbound Logistics, 67

Packaging, 46

Patterns of Brand loyalty, 45

Penetration Pricing, 51, 61

Personalised marketing, 99

Physical Distribution Mix, 66

PLC model, 40

Post Launch analysis, 36 
Prestige Pricing, 51

Premium Pricing, 51

Premium/Prestige Pricing, 61

Price, 54

Price Mix, 54

Price Penetration, 63

Price skimming, 61

Price Skimming, 51, 63

Pricing methods, 59

Pricing of a new product, 62

Pricing of Products, 49, 56

Pricing Policies, 50

Product, 30

Product Concept, 5

Product creation, 35

Product design, 34

Product development, 33

Product Differentiation, 26

product era, 87

Product image, 46

Product Labeling, 47

Product Life Cycle, 38

Product line, 32

Product mix, 32

Product Positioning, 23

Production Concept, 5

production era, 87

Promotional Pricing, 52, 61

Prototype Development, 35

Prototype Testing, 35

Psychographic Variables, 20

Re Marketing, 98

relationship era, 88

Relationship marketing (RM), 89

Relationship-Based Pricing, 60

Retail Price Maintenance, 63

Responsibility Marketing, 94

Retailing, 77

Risk Assessment , 9
Role of Middlemen, 70

Role of packaging, 46

Role of pricing, 56

sales era, 87

Scope of Modern Marketing, 90

Search Engine Marketing, 100

Selective Demarketing, 98

Selling Concept, 5

SEM, 100

SEO, 100

Service Marketing, 95

Service Marketing Mix, 95

Setting price objective, 58

Social Marketing, 94

Social Media Marketing, 101

Socially-oriented pricing, 60

Societal Marketing Concept, 6

socio - economic variables, 17

Specialty Stores, 79

Speed Marketing, 97

Stages of PLC, 39

Steps in formulating pricing, 58

Steps in Market Targetting, 22

Supermarket, 78

Supplier Logistics, 67

Supply Chain Management, 67

Synchro Marketing, 95

Task environment, 7

Target Marketing, 22

Telemarketing, 93

Test Marketing, 36

Trade Channels, 69

Trends in Marketing, 91

Types of brand, 42

Types of channel conflict, 76

Types of Channels, 69

Types of label, 48

Types of Logistics, 67

Types of Online marketing, 100 
Types of Pricing, 51, 60

Types of Product, 31

Types of retailing, 77

Types of Telemarketing, 93

Turbo-Marketing, 97

Umbrella Branding, 42

Un selling, 97

Undifferentiated Mkting, 26
Value based pricing, 60

VMS, 72

Viral Marketing, 94

Viral advertising, 94

Warehouse Stores, 78

Word of Mouth Mkting, 94 


\section{BIBLIOGRAPHY}

1. Activbook, A. K. (2006). Principles of Marketing. Australia: Pearson Education .

2. Brown \& Armstrong:Activbook, A. K. (2006). Principles of Marketing (3 ed.). Pearson Education Australia.

3. Dean, J. (1976). Pricing Policies for New Products. Harvard Business Review.

4. Gary M. Armstrong, G. A. (2007). Marketing: An Introduction (8 ed.). (P. Kotler, Ed.) Pearson Prentice Hall.

5. Gary M. Armstrong, S. A. (2014). Principles of Marketing. Pearson.

6. Gilliland, D. (2005). Marketing. Institute of Financial Services.

7. Govindarajan, M. (N.D.). Marketing Management. 2007: PHI Learning Pvt. Ltd.

8. Kotler, P. (2000). Kotler on Marketing. Simon \& Schuster.

9. Kotler, P. (2003). A Framework for Marketing Management. Prentice Hall.

10. Kotler, P. (2009). Marketing Management. Pearson Prentice Hall.

11. Kotler, P. (2017). My Adventures in Marketing: The Autobiography of Philip Kotler (Kindle Edition ed.). Idea Bite Press.

12. Kotler, P. (n.d.). Marketing Management: A South Asian Perspective (13 ed.). Pearson Education India.

13. Kotler, P. (n.d.). Ten Deadly Marketing Sins: Signs and Solutions. John Wiley \& Sons. 
14. Nancy R. Lee, P. K. (n.d.). Social Marketing: Influencing Behaviors for Good (4 ed.). Delhi: SAGE Publications India.

15. Philip Kotler, D. C. (n.d.). Marketing Moves: A New Approach to Profits, Growth, and Renewal. Harvard Business Press.

16. Philip Kotler, G. A. (2016). Principles of Marketing, Global Edition. Pearson Education Limited.

17. Philip Kotler, H. K. (2010). From Products to Customers to the Human Spirit. John Wiley \& Sons.

18. Philip Kotler, K. L. (n.d.). Marketing Management. Pearson Education India.

19. Philip, K. (n.d.). Marketing Management . Pearson.

20. VS Ramaswamy, S. N. (n.d.). Marketing Management: Global Perspective, Indian Context. Macmillan.

\section{WEBSITES}

www.yourarticlelibrary.com

https://www.researchgate.net

https://www.marketing-schools.org

https://www.investopedia.com

https://www.marketing-schools.org

http://www.creativeguerrillamarketing.com

https://www.smallbusiness.com

www.businessdictionary.com 